\title{
Uniform Acts, Restatements, and Trends in American Trust Law at Century's End $\dagger$
}

\author{
Edward C. Halbach, Jr.
}

TABle of Contents

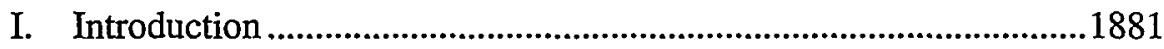

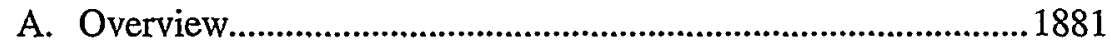

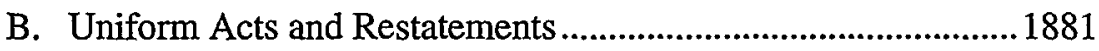

II. Definition and Concept: Trusts as "Entities"..................................1882

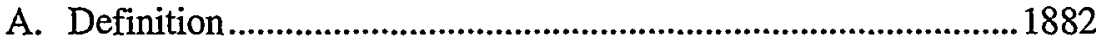

B. Increasing Recognition as an Entity ..........................................1882

III. Leniency in Determining the Validity and

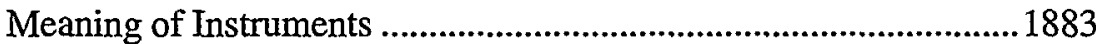

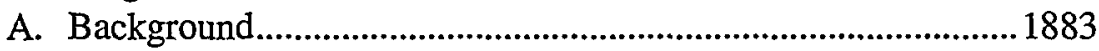

B. Doctrines of Substantial Compliance ...........................................1884

C. Interpretation, Reformation, and Modification ........................... 1885

1. Curing Ambiguity ..................................................................1885

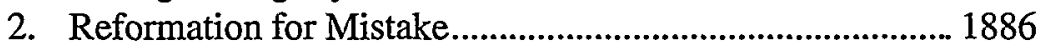

3. Modification: Tax Objectives ............................................1887

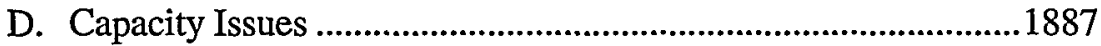

E. Revocable Inter Vivos Trusts ...................................................1888

IV. Limitations on Permissible Dispositions ......................................... 1890

Copyright (C) 2000 Edward C. Halbach, Jr. California Law Review, Incorporated (CLR) is a California nonprofit corporation. CLR and the authors are solely responsible for the content of their publications.

$\dagger \quad$ This Essay is based on a piece originally published in 25 ACTEC Notes (Fall 1999), expanding on the author's Joseph Trachtman Lecture at the 1999 Annual Meeting of the American College of Trust and Estate Counsel (ACTEC).

$\doteqdot \quad$ Walter Perry Johnson Professor of Law, Emeritus, School of Law, University of California, Berkeley (Boalt Hall). The author is the reporter for the Restatement (Third) of Trusts, was coreporter for the Uniform Probate Code, and currently serves in advisory roles for the Uniform Trust Code and Restatement (Third) of Property: Wills \& Other Donative Transfers.

EDITOR'S NOTE: At the time this Essay was written, the Uniform Trust Code discussed throughout the text was still in development by the National Conference of Commissioners on Uniform State Laws (NCCUSL). The Code has since been approved with modest changes in the content or in the numbering of a few sections. Therefore, some sections of the draft Code referenced in this Essay may not precisely correspond to sections of the Code as promulgated. 
A. "Not Unlawful or Contrary to Public Policy" ............................1890

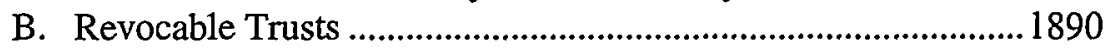

C. Trust Conditions Contrary to Public Policy...............................1891

D. Rule Against Perpetuities and Related Doctrine ........................1893

E. Restraining Voluntary and Involuntary

Alienation: Spendthrift and Discretionary

Trusts

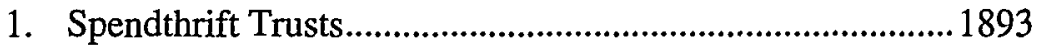

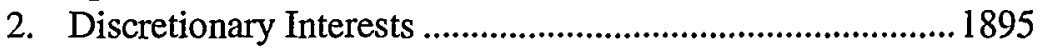

F. Softening of the Definite Beneficiary

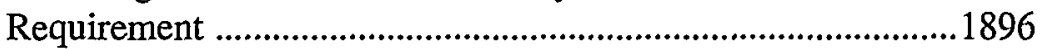

V. Revocation, Termination, and Modification of Trusts .......................1898

A. Settlor's Powers to Revoke and Amend .....................................1898

1. Settlor's Implied Power to Revoke ...................................... 1898

2. Exercise of Power to Revoke or Amend ............................ 1898

B. Beneficiary Power and Judicial Authority

to Terminate or Modify a Trust ................................................. 1899

1. Modification or Termination by

Consent of the Beneficiaries ...............................................1900

2. Judicial Power: "Equitable Deviation" ..............................1900

C. Charitable Trusts: The Cy Pres Doctrine .................................... 1901

VI. Clarifying and Modernizing Significant Rules of

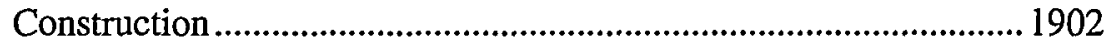

A. Remainders and Other Future Interest Problems.......................1902

1. Survivorship Requirements................................................. 1903

2. Definitional Problems in Class Gifts.................................1904

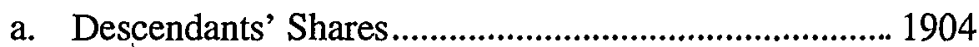

b. Status of Adoptees.......................................................1905

c. Status of Nonmarital Children ......................................1905

3. Rejection of the Doctrine of Cross Remainders ................. 1906

B. Construction and Enforcement of Discretionary

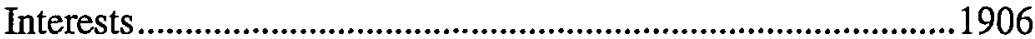

VII. The Office of Trustee; Fiduciary Duties and Standards ............... 1908

A. Decision Making by Multiple Trustees ..................................... 1908

B. Resignation and Removal of Trustees .....................................1908

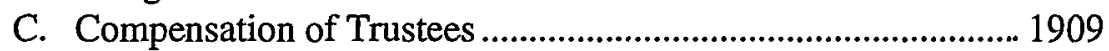

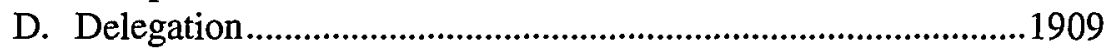

E. The Duty of Loyalty ..............................................................1911

F. The Duty of Impartiality, Including "Productivity" and Principal-Income Accounting.......................................... 1912

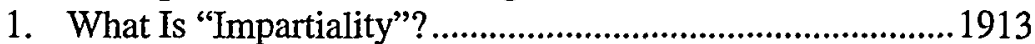

2. Trust Design and Accounting ............................................. 1913 
G. Trustees' Duties with Respect to Accounting and Disclosure

1. Trusts Containing Powers of Appointment ...........................1915

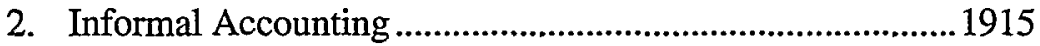

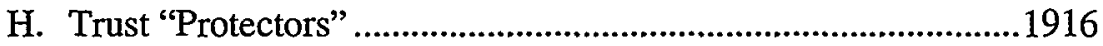

I. Liability of Trustees .............................................................1917

VIII. Investment and Management of Trust Property.............................1918

A. Trust Investment Law ................................................................... 1918

B. Trust Management Generally .....................................................1920

IX. Concluding Observations............................................................... 1921 
[Vol. 88:1877 


\title{
Uniform Acts, Restatements, and Trends in American Trust Law at Century's End
}

\author{
Edward C. Halbach, Jr.
}

\author{
I \\ INTRODUCTION
}

\section{A. Overview}

In the last third of this century, and particularly in the last decade, trust law in the United States has experienced a period of rigorous, comprehensive reexamination. Some of this reexamination has involved adaptation to the gradual evolution of trust practice, and of related tax law and planning, over a considerably longer period of time.

A pervasive theme of recent years' developments and current trends is that ascertainable intentions of transferors should be given effect, despite technical deficiencies, when there is reliable direct or circumstantial evidence of a properly developed intention that is not unlawful or contrary to public policy. Another theme is flexibility and efficiency in the pursuit of the best interests of trust beneficiaries within the settlor's legally permissible objectives.

\section{B. Uniform Acts and Restatements}

The promulgation of a "uniform act" or "uniform code" by the National Conference of Commissioners on Uniform State Laws (NCCUSL) merely recommends the act for adoption in the various states. The uniform act must then be enacted by the legislatures of individual states in order to become law in those jurisdictions. A Uniform Trust Code is currently in the final stages of development, with NCCUSL promulgation likely in the near future.

Restatements are produced under the auspices and must receive formal approval of the American Law Institute (ALI); they purport to state an authoritative or recommended view of current American common law. Both a Restatement (Third) of Trusts (hereinafter simply "Trusts Third") and a Restatement (Third) of Property: Wills \& Other Donative Transfers (hereinafter "Property Third") are currently in process and at various stages of planning, drafting, or approval by ALI. All sections of Trusts Third and Property Third hereafter cited, in text or footnotes, have received at least 
tentative approval by ALI, although most of these sections are still designated as "tentative drafts."

\section{III}

Definition and Concept: Trusts as "Entities"

\section{A. Definition}

Trusts Third section 2 essentially restates the definition found in prior Restatements and often quoted in cases and texts: "A trust ... is a fiduciary relationship with respect to property, arising as a result of a manifestation of intention to create that relationship and subjecting the person who holds title to the property to duties to deal with it for the benefit of charity or for one or more persons, at least one of whom is not the sole trustee." 2

Without abandoning the basic definition of a trust as a fiduciary relationship, there appear to be subtle but practically significant departures from the traditional concept that a trust is not an "entity."

\section{B. Increasing Recognition as an Entity}

Courts generally continue to deny that trusts are legal entities, at least in dictum. ${ }^{3}$ The tax law, however, has long treated the typical trust as an entity separate from the person who serves as trustee. ${ }^{4}$

An increasing number of states draw a distinction for various purposes between the trustee personally and the trustee's fiduciary or "representative" capacity. These purposes range from eliminating the awkward traditional view that a trustee's note to the trust cannot be trust property ("After all, one cannot be indebted to oneself"!) to escaping the traditional view that trustees can neither sue nor be sued in their fiduciary capacity, so that, when successful, a third party's suit results in a judgment against the trustee personally, with the trustee left to seek reimbursement

I. Approval of a "tentative draft," without publication in final form, enables the reporter to refine, adapt, or modify the content and structure and to completc cross-refercnces to subsequent sections as the project proceeds. Except for the 1992 publication of the "Prudent Investor Rule" volume (see infra Part VIII), it is presently contemplated that the various volumes of Trusts Third will remain in tentative draft until the entire project is completed.

2. Restatement (ThIRD) of TRUSTS $\S 2$ (Tentative Draft No. 1, I996) [hereinafter Trusts THIRD].

3. For example, see McBee v. Vandecnocke Revocable Trust, No. WD 54506, 1998 WL 201743, at *2 (Mo. Ct. App. Apr. 28, 1998), aff'd as modified, 986 S.W.2d 170 (Mo. 1999), although the holding that the trustee was an indispensable party to a third party's action could just as well have applied to the trustee in a representative capacity. For a thoroughly sensible recent decision made difficult by this traditional notion, see Ziegler v. Nickel, 64 Cal. App. 4th 545 (Ct. App. 1998).

4. See, e.g., I.R.C. $\$ \S 641-679$ (1998) (Subchapter J).

5. The traditional view stated in RESTATEMENT (SECOND) OF TRUSTS $\$ 87$ (1959) has been superseded by TRUSTS TH1RD, supra note $2, \S \S 2 \mathrm{cmt}$. i \& $40 \mathrm{cmt}$. b, and also by widespread, accepted practices. See id. $\$ 2 \mathrm{cmt}$. i, reporter's note. 
from the trust estate. ${ }^{6}$ Most importantly, Trusts Third can be expected to reverse the position of previous Restatements of Trusts ${ }^{7}$ by providing that third parties' suits against trustees normally result in a judgment against the trustee in a representative capacity (that is, one "against the trust"). A legislative shift in this direction, initially affecting only estate administration, was stimulated by the promulgation of the Uniform Probate Code in 1969. In trust administration, this view is being proposed (without any apparent opposition) in the 1999 draft of the Uniform Trust Code. ${ }^{9}$

III

\section{LENIENCY IN DETERMINING THE VALIDITY AND MEANING OF INSTRUMENTS}

\section{A. Background}

Property owners today generally have longer life spans and often live into substantial periods of diminished physical or mental health. Trusts are also now being used by broader segments of society than in the past, and with greater diversity of objectives (ranging from tax and probate avoidance, to property management late in life, to highly sophisticated multifamily, multigeneration plans of disposition), but increasingly without aid of legal counsel who are skilled in the complexities of estate and trust planming. ${ }^{10}$ Perhaps these are all significant factors in the tendency of the law to provide "user friendly" responses" to inany of the legal questions considered hereafter, making trust law more sympathetic to the results of

6. See UNIF. TRUST CODE $§ 1108$ (c) (Discussion Draft Feb. 9, 1999) (abandoning this view).

7. See Restatement (SECOND) OF TRUSTS $\$$ 261-265.

8. See Unif. Probate Code § 7-306 (1998); see also, e.g., CAL. Prob. Code \$§ 18000-18003 (West 1998); GA. CODE ANN. § 53-12-199(b) (1998); MAss. GEN. LAWs. ch. 203, § 14A (1990).

9. See UN1F. TRUST CODE $\S 1108$ (a) (Discussion Draft Feb. 9, 1999) (stating that unless "otherwise agreed, a trustee is not personally liable on a contract properly entered into in the trustee's fiduciary capacity in the course of administration of the trust if the trustee in the contract discloses the fiduciary capacity"); id. §1108(b) (stating that trustees are "personally liable for torts committed in the course of administering a trust, or for obligations arising from ownership or control of trust property, including liability for violation of environmental law, only if the trustee is personally at fault") (emphasis added); id. § 1108(c) (allowing claims to "be asserted against the trust in a judicial proceeding against the trustee in the trustee's fiduciary capacity, whether or not the trustee is personally liahle on the claim").

For general discussions of trusts as entities, see Tatarian v. Commercial Union Insurance Co., 672 N.E.2d 997, 1000 (Mass. App. Ct. 1996) (noting that although the "entity" in a prior case was "a corporation rather than a trust," the court was not "persuade[d] ... that a different analysis should therefore apply"); TRUSTs THIRD, supra note 2, $\$ 2 \mathrm{cmt}$. a \& reporter's notes; Jeffrey Schoenblum, The Hague Convention on Trusts: Much Ado About Very Little, $3 \mathrm{~J}$. OF INT'L TR. \& CoRP. Plan. 5, 14 (1994) ("The Convention ... requires recognition of the trust as a distinct legal entity .... Article 11 sets forth certain attributes of the trust that must be recognized. These essentially pertain to the distinction between the trustee acting as a fiduciary and the trustee acting in his individual capacity.").

10. See, e.g., Joel C. Dobris, Changes in the Role and the Form of the Trust at the New Millennium, or, We Don't Have to Think of England Anymore, 62 ALB. L. REv. 543 (1998).

11. See supra Part I.A. 
error or oversight and more sensitive to the broad variety of trusts, trusteeships, settlor objectives, and the needs and circumstances of the beneficiaries.

\section{B. Doctrines of Substantial Compliance}

The Uniform Probate Code, Trusts Third, Property Third, and beginning but distinct trends in other statutory and common law authorities are all moving American law in the direction of upholding property owners' attempts to create wills and trusts in situations in which traditional law would have found an execution or transfer defective, or an expression of trust or other dispositive intention deficient, on some technical or formal ground. This liberalization, however, remains subject to a requirement of evidentiary and circumstantial security that the trust represents an intention the testator or settlor has reasonably considered and undertaken to implement.

The trend toward liberalization can be seen in legislative or judicial acceptance of some form of "harmless error" (or "substantial compliance" or "dispensing power") doctrine, especially in the law of wills." The trend can also be seen in inter vivos trust creation in an increased tolerance for certain failures to satisfy the mandates of the Statute of Frauds ${ }^{13}$ or the requirements for a completed inter vivos transfer. ${ }^{14}$

In addition, the trend is apparent in increasingly sympathetic views of attempts to create "secret" or "semisecret" testamentary trusts, ${ }^{15}$ and to pour testamentary assets into amendable and revocable, funded, or unfunded inter vivos trusts. Liberalized "pour over" rules result not only from various versions of the Uniform Testamentary Additions to Trusts Act but also from better understanding of general principles that can appropriately be applied in the absence of such legislation. ${ }^{16}$

The original and revised provisions of the Uniform Probate Code suggest legislation allowing testamentary disposition of certain tangible

12. See, e.g., UNIF. Probate Code § 2-503 (1990); Faith v. Singleton, 692 S.W.2d 239 (Ark. 1985); In re Will of Ranney, 589 A.2d 1339 (N.J. 1991); see also RESTATEMENT (THIRD) OF Property: Wills and Other Donative Transfers $\$ 3.3$ (Tentative Draft No. 2, 1998) [hereinafter Property THIRD]; John H. Langbein, Excusing Harmless Errors in the Execution of Wills: A Report on Australia's Tranquil Revolution in Probate Law, 87 Colum. L. Rev. 1 (1987); cf. Hickox v. Wilson, 496 S.E.2d 711 (Ga. 1998); In re Trust Estate of Daoang, 953 P.2d 959 (Haw. Ct. App. 1998) (trust amendment). But see Stevens v. Casdorph, 508 S.E.2d 610, 615 (W. Va. 1998) (dissenting opinion) (calling will's rejection an "abandon[ment of] common sense ... in favor of technicalities"). Stevens is described as a "textbook example" of the need for the Uniform Probate Code's "dispensing power” in Ronald D. Volkmer, New Fiduciary Decisions, 26 EsT. PLAN. 189, 191 (1999).

13. See TRusts THIRD, supra note $2, \S 24$.

14. See id. § 160; see also, e.g., Vasquez v. Vasquez, 973 S.W.2d 330 (Tex. App. 1998).

15. See, e.g., TRUSTS THIRD, supra note $2, \S 18 \mathrm{cmts.}$ b, c.

16. See id. §19. Also, on pour-over dispositions (and on the inverse, the "pouring up" of outside assets into testamentary trusts), see PROPERTY THIRD, supra note $12, \S 3.8$ (relying on incorporation by reference and particularly on a sound application of the independent significance doctrine). 
personal property as directed by writings that do not satisfy Wills Act formalities. $^{17}$

\section{Interpretation, Reformation, and Modification}

A similar liberalization is discernible in a recent tendency to soften traditional obstacles to the discovery and implementation of the specific intentions or general objectives, as the case may be, of testators and settlors. A particular target of this trend is the so-called "single plain meaning rule," which bars extrinsic evidence of intent when a document's meaning is deemed clear. Evolving doctrine, however, continues to seek reasonable evidentiary reliability in these matters.

\section{Curing Ambiguity}

Traditional doctrine has recognized that extrinsic evidence may be admitted and considered in order to clarify "ambiguities" (a term generally used to encompass all uncertainties of meaning), althougl a distimction has often been drawn between "latent" and "patent" ambiguities, a distinction that usually has been finessed, ignored, or simply overlooked, or, often in more recent years, openly rejected. ${ }^{18}$ Furthermore, over fifty years ago, the original Restatement of Property stated that a transferor's intent "is normally determined by the language employed ..., read as an entirety and in the light of the circumstances of its formulation." ${ }^{19}$ Comment $c$ to that section added that "in so far as [the 'single plain meaning rule' causes exclusion of the circumstances of an instrument's formulation, it] is disapproved, since language is so colored by the circumstances of its formulation that the exclusion of otherwise admissible evidence as to such circumstances is never justified." Unfortunately, however, the line between evidence of "circumstances" and other types of extrinsic evidence is not always readily drawn. Further developments in a few states were fostered largely by California's Estate of Russell ${ }^{21}$ and New Jersey's Engle v. Siegel. ${ }^{22}$

17. See UNIF. Probate CODE $\S 2$-513. Statutes of this type are collected in Property THIRD, supra note $12, \S 3.9$ statutory note 3 .

18. See, e.g., Eugene F. Scoles \& Edward C. Halbach, JR., Materials on Decedents' ESTATES AND TRUSTS 166-94 (5th ed. 1993).

19. Restatement OF Property \$ 242 (1940).

20. Id. $\$ 242 \mathrm{cmt}$. $\mathrm{c}$.

21. 444 P.2d 353 (Cal. 1968). Estate of Russell emphasized that whether or not a will is "ambiguous" cannot always be determined "until the surrounding circumstances" and possibly other forms of "extrinsic evidence" are "first considered." Id. at 361-62. If "in light of such extrinsic evidence the provisions of the will are not reasonably susceptible of two or more meanings," evidence is not admissible to show "an intention different from that expressed by the words"- - that is, to show a meaning of which the words are not "reasonably susceptible." Id.

22. 377 A.2d 892 (N.J. 1977). Engle summarizes New Jersey's even greater departure from tradition through "what has come to be known as the doctrine of probable intent," under which "a court not only examines 'the entire will' but also studies 'competent extrinsic evidence'; it attributes to the 
More recently, Property Third states: "An ambiguity in a donative document is an uncertainty in meaning that is revealed by the text or by extrinsic evidence other than direct evidence of intention contradicting the plain meaning of the text."23 It further provides that an ambiguity "to which no rule of construction or constructional preference applies" is to be resolved "in accordance with the donor's intention, to the extent that the donor's intention is established by a preponderance of the evidence."24 Where a rule of construction or, in the absence thereof, a constructional preference applies, Property Third provides that the ambiguity is resolved by the rule or preference (or most persuasive of multiple preferences) "unless evidence establishes that the donor had a contrary intention." 25

\section{Reformation for Mistake}

A more dramatic departure from tradition is found in Property Third's approach to reformation for mistake. ${ }^{26}$ That section states:

A donative document, though unambiguous, may be reformed to conform the text to the donor's intention if the following are established by clear and convincing evidence:

(1) that a mistake of fact or law, whether of expression or inducement, affected specific terms of the document; and

(2) what the donor's intention was. ${ }^{27}$

The section continues: "Direct evidence of intention contradicting the plain meaning of the text as well as other evidence of intention may be considered in determining whether elements (1) and (2) have been established by clear and convincing evidence." 28

testator 'common human impulses' and seeks to find what he would subjectively have desired had he in fact actually addressed the contingency which has arisen." Id. at 894.

23. PROPERTY THIRD, supra note $12, \S 11.1$.

24. Id. § 11.2 (emphasis added).

25. Id. $\$ 11.3$.

26. See id. § 12.1 .

27. Id. (emphasis added).

28. Id.; see also Erickson v. Erickson, 716 A.2d 92 (Conn. 1998) (holding that evidence of scrivener's mistake should have been admitted in will proceeding).

The Greensboro News \& Record carried a story that seems to invite an obvious question: Shouldn't the law offer an alternative to self-help remedies for "scriveners' errors"?

Johnson City, Tenn.-A single word apparently cost 81-year-old lawyer John Goodin his life.

Goodin left out the word "stock" from a woman's will and her ex-husband, Walter Shell believed that omission cost him up to $\$ 100,000$.

On Thursday, police say, an enraged Shell went to Goodin's law office and shot him to death....

....

... Shell and his daughters equally divided $\$ 12,000$ from an insurance policy. Katie Shell also left him a car and lawnmower.

The revised will also stipulated Shell was to receive "all monies" after the legal costs for the estate were paid. His daughters ... claim[ed] that since the word "stock" was not included, Walter Shell was not entitled to any of the $\$ 100,000$ in shares their mother owned.

A judge agreed .... 
Courts are also beginning to show, properly it would seem, increased willingness to supply gifts by implication, especially in trust settings, when evidence or context clearly justifies doing so. ${ }^{29}$

\section{Modification: Tax Objectives}

Property Third section 12.2 importantly states that a court may modify a "donative document . . . in a manner that does not violate the donor's probable intention, to achieve the donor's tax objectives." ${ }^{30}$ This is an important provision because tax statutes or regulations sometimes authorize the terms of a disposition to be modified to conform to existing or subsequently enacted Internal Revenue Code requirements.

Property Third distinguishes, properly it would seem, between "reformation" to correct the language of a document to reflect the intention, or the overriding intention, of a transferor, and "modification" to insert changes that were not intended by the transferor but that would allow accomplishment of a tax objective (established by a preponderance of the evidence), provided the modified terms would not be in violation of any probable intention of the transferor. ${ }^{31}$ The reporter's notes to sections 12.1 and 12.2 show how and when reformation of a trust or other disposition to get its terms "right" $a b$ initio and modification can be reconciled with the doctrine of Commissioner v. Estate of Bosch, ${ }^{32}$ limiting the circumstances in which federal taxing authorities are "bound" by probate or other state court decrees. ${ }^{33}$

Analogous issues relating to inodification and termination by beneficiaries or courts are considered in infra Parts V.B and V.C.

\section{Capacity Issues}

Trust law is finally beginning to clarify and refine rules concerning capacity to create, amend and revoke inter vivos trusts, recognizing particularly that the degree of capacity required to create a revocable inter

Man Kills Lawyer Who Left Word out of Will, GREENSBORo News \& REC., Mar. 20, 1999, at A5.

29. See, e.g., In re Bieley, 695 N.E.2d 1119 (N.Y. 1998). Also, as discussed in infra Part VI.A.3, TRusts THIRD, supra note $2, \S 49 \mathrm{cmt}$. $\mathrm{c}$ generally recognizes an implied disposition of income, to replace the traditional doctrine of cross-remainders in income.

30. PROPERTY ThIRD, supra note $12, \$ 12.2$.

31. For a recent IRS recognition of a court's power to "reform" for scrivener's error (mistake of omission), see Priv. Ltr. Rul. 98-32-039 (May 13, 1999) (cosettlors of irrevocable life insurance trust reserved joint power to remove trustee, omitting intended "for cause" limitation). Actually going a step further is the modification (called a "reformation" by the court) to avoid "unintended and undesirable" tax consequences in Fleet Bank v. Fleet Bank, 706 N.E.2d 627, 628 (Mass. 1999).

32. 387 U.S. 456 (1967).

33. See PROPERTY THIRD, supra note $12, \$ \S 12.1,12.2$ reporter's notes. 
vivos trust should be no higher than that required to execute a valid will under traditional, quite standard probate law. ${ }^{34}$

The standard of capacity for the creation of an irrevocable inter vivos trust should depend on whether the trust is purely donative, in which case a gift standard is appropriate, or whether it is part of a negotiated or adversary transaction, for which the higher contract standard would be appropriate. Trusts Third section 11(3), comment c, explains that the gift standard is the will standard plus an "ability to understand the effects the disposition may have on the future financial security" of the settlor and his or her dependents. ${ }^{35}$ For trusts created incident to divorce or a commercial transaction, for example, that comment incorporates the standard of capacity stated in Restatement (Second) of Contracts section 12. ${ }^{36}$

The law in the various states is similarly beginning to come to grips with issues concerning the creation, amendment, and revocation of trusts on behalf of incapacitated persons by their personal fiduciaries, such as agents acting under express provisions of durable powers of attorney and conservators exercising substituted judgment with court approval. The tendency here is, with proper safeguards, to avoid wholly denying incapacitated persons and their families the benefits of clarification or updating of estate plans and the adaptation of those plans (including plans that would be established by operation of law) to changed legal, financial and family circumstances or objectives. ${ }^{37}$ Of course, the most obviously appropriate, but not the only, example of action to be taken by a personal fiduciary would be the establishment of a probate-avoidance plan that substitutes a revocable trust for a will without changing the dispositive plan.

\section{E. Revocable Inter Vivos Trusts}

Earlier concerns and uncertainties about the validity of revocable living trusts (Are they "testamentary"?) have been resolved gradually over the last half century in nearly all states. These developments, offering a settlor alternatives and freedom of choice in inatters of mere form (avoiding Wills Act fornalities) and procedure (avoiding the probate process), are to be distinguished from the serious matters of substantive policy, considered hereafter in Part IV.B, limiting the effects of even valid revocable trusts.

34. See TRUSTs ThIRD, supra note $2, \S 11(2) \mathrm{cmt}$. b, quoted with approval in In re Estate of Aronoff, 653 N.Y.S.2d 844, 847 n.6 (Sup. Ct. 1996); see also UNIF. Trust CodE \$ 601 (Discussion Draft Feb. 9, 1999) (adopting Trusts Third view); Lah v. Rogers, 707 N.E.2d 1208, 1214 n.7 (Ohio Ct. App. 1998) (applying will standard of "testamentary capacity" to revocable living trusts).

35. TRUSTS THIRD, supra note $2, \S 11(3) \mathrm{cmt}$. c.

36. See REstATEMENT (SECOND) OF CONTRACTS $§ 12$ (1979).

37. See TRUSTs THIRD, supra note $2, \S 11(5) \mathrm{cmts}$. e, f (on preserving, perfecting, or altering an existing estate plan). For a recent case considering and discussing substituted judgment, sce $I n$ re Estate of Berry, 972 S.W.2d 324 (Mo. Ct. App. 1998). 
Trusts Third section 25(1) crystallizes and advances this trend to uphold revocable trusts, with solid support in statutes, case law and practice today in the vast majority of jurisdictions. ${ }^{38}$ The section states:

A trust that is created by the settlor's declaration of trust, by his or her inter vivos transfer to another, or by beneficiary designation or other payment under a life insurance policy, employee benefit or retirement arrangement, or other contract is not rendered testamentary merely because the settlor retains extensive rights such as beneficial interest for life, powers to revoke and modify the trust, and the right to serve as or control the trustee, or because the trust is funded in whole or in part or comes into existence at or after the death of the settlor, or because the trust is intended to serve as a substitute for a will. ${ }^{39}$

The first part of Trusts Third section 25(2) contmues with the related and now similarly well established proposition that a trust that is "not testamentary"- - that is, not actually created by will- "is not subject to the formal requirements of $\S 17$ [on Wills Act formalities] or to procedures for the administration of a decedent's estate." 40

As with irrevocable inter vivos trusts, a revocable living trust may be created either by transfer (to another as trustee) or by declaration (with the settlor serving as the trustee). Trusts Third section 10, cominent e, like its predecessor, ${ }^{41}$ provides that a declaration of trust is valid and effective without actually transferring or re-registering intended trust assets into the name of the settlor as trustee, as long as the instrument declaring the trust identifies those assets. ${ }^{42}$ This validates the practice of attaching a schedule listing the assets that are to be held in the trust without executing separate instruments of transfer, in the absence of a statutory requirement that goes beyond the usual recording act. ${ }^{43}$ For practical reasons, steps should ordinarily be taken at the time the trust is created to conform ownership documents or records, and thereby to perfect the rights and interests of the trustee and beneficiaries with respect to third persons. As long as the trust is effectively established, however (and assuming inconsistent third-party rights have not by then intervened), these steps may be taken later by the settlor or, even after the settlor's death or incompetency, by court order or other procedures appropriate to the circumstances and applicable law or practice.

\footnotetext{
38. See TRUSTS THIRD, supra note $2, \S 25$ cmts. b \& c, reporter's notes.

39. Id.; cf. UnIF. PROBATE CODE § 2-907(b) (1990).

40. TRUSTs THIRD, supra note $2, \S 25(2)$. Other aspects of this Trusts Third subsection are considered in infra Part IV.B.

41. See Restatement (SeCOND) OF Trusts $\$ 17 \mathrm{cmt}$ a a (1959).

42. See TRUSTs THIRD, supra note $2, \S 10 \mathrm{cmt}$. e.

43. The few cases on point support this Restatement rule. See, e.g., Heggstad v. Heggstad (Estate of Heggstad), 16 Cal. App. 4 th 943 (Ct. App. 1993).
} 
Similarly, the new Restatement takes the position that a writing signed and delivered by the settlor, or a trust agreement executed by the settlor and trustee, manifesting the settlor's present intention thereby to transfer specified property (such as all property listed or described in an attached schedule) is sufficient to create a trust by transfer to another as trustee. ${ }^{44}$ Even additional statutory formalities, such as those applicable to transfers of land requiring that a document be sealed, attested, acknowledged, or recorded, ordinarily are not essential to effect a transfer as between transferor and transferee. ${ }^{45}$ It is not recommended, of course, that settlors rely on these rules but rather that they perfect the trustee's title by formal transfers involving re-registration or execution and recordation of deeds of transfer.

\section{IV}

Limitations on Permissible Dispositions

A. "Not Unlawful or Contrary to Public Policy"

Even the liberalized rules for determining validity and ascertaining the meaming of inter vivos and testamentary documents remain subject to the traditional, fundamental principle that a testator's or settlor's intention is to be given effect only so far as that intention is not unlawful or contrary to public policy. It therefore becomes important to examine Uniform Acts, Restatements, and other recent developments to identify important trends or possible trends in policy-based rules that may directly or indirectly limit freedom of disposition, either in terms of what can be left to whom, or in terms of the allowable nature and extent of dead-hand control.

\section{B. Revocable Trusts}

After declaring the general validity of revocable trusts, ${ }^{46}$ Trusts Third section 25(2) continues: "[N]evertheless, a revocable inter vivos trust is ordinarily subject to substantive restrictions on testation ... and other rules applicable to testamentary dispositions, and in other respects the property of such a trust is ordinarily treated as if it were owned by the settlor." ${ }^{47}$ As the commentary explains, the first two lines of this statement mean that the

44. See Trusts ThIRD, supra note $2, \S 16 \mathrm{cmt}$. b; see also UNIF. TRust Code $\S 401$ (b) (Discussion Draft Feb. 9, 1999) ("The terms of a trust instrument may serve as a deed of conveyance 10 a trustee or subject identified property to a self-declaration of trust.") (emphasis added); $c f$. Binder v. Binder, 386 N.W.2d 910 (N.D. 1986) (holding that a trust of land was created, without a deed, by intention and other elements shown in a divorce settlement agreement); Ballard v. McCoy, 443 S.E.2d 146 (Va. 1994) (finding a signed trust agreement with appended list of assets insufficient to create a trust by transfer, but apparently only because the document specified the settlor's intention that the trust should coine into being only when the "property" is later "delivered" by the settlor to the trustees).

45. See Restatement (Second) of Property: Donative Transfers $\S 32.3 \mathrm{cmt}$. a (1992).

46. See supra Part III.E.

47. TRUsts ThIRD, supra note $2, \S 25(2)$. 
trust property is subject to the statutory forced share of a surviving spouse and to the claims of creditors of a deceased settlor's estate..$^{48}$ Although the above-quoted rule of Trusts Third represents an ongoing trend of statute and case authority, it presently lacks consistent support from state to state. ${ }^{49}$

Although not involving restrictions on testation or on trust provisions, it seeins worth noting here that Trusts Third section 25(2) also calls generally for the application of "rules of construction and other rules applicable to testamentary dispositions" to revocable living trusts..$^{50}$ Included would be pretermitted heir and antilapse statutes, and legislation providing for revocation upon divorce of certain will provisions for the testator's former spouse. ${ }^{51}$ Also, under Trusts Third, property of a revocable trust is ordinarily to be treated as if it were owned by the settlor and not by the beneficiaries. $^{52}$

\section{Trust Conditions Contrary to Public Policy}

Perhaps inoving in an understandably restrictive direction is the inevitably more subjective body of doctrine concerning trust provisions that may be contrary to or limited by public policy on grounds other than those considered later in Parts IV.D and IV.E. A lengthy Restatement section on inpermissible conditions has just received ALI approval.

Trusts Third section 29(b), with associated comments $d$ through $h$, is designed to clarify, with the general effect of limiting, the extent to which settlors may subject the interests of trust beneficiaries to conditions that tend seriously to intrude upon significant personal decisions, and the private lives of beneficiaries and their families. Conditions that may be

48. See id. cmts. d, e; see also id. §§ 34.1(3), 34.3(3); UN1F. Probate Code § 2-202(b)(2) (1990).

49. See generally cases and statutes collected in TRUSTS THIRD, supra note $2, \S 25(2) \mathrm{cmts}$. d, e reporter's notes. Section 25(2) reverses the positions of RESTATEMENT (SECOND) OF TRUSTS $\$ 57 \mathrm{cmt}$. d (1959) (on spousal share) and id. $\$ 330 \mathrm{cmt}$. o (on creditors of settlor or settlor's estate). On creditors' rights, Phillips v. Rose (In re Estate of Nagel), 580 N.W.2d 810 (lowa 1998), recently joined cases supporting the Trusts Third position. On the spousal share, see Dunnewind v. Cook, 697 N.E.2d 485 (Ind. Ct. App. 1998) (finding fraud on the widow's share), but compare Pezza v. Pezza, 690 A.2d 345 (R.I. 1997) (finding trust not "illusory" for this purpose). Leading Massachusetts cases support both of the Trusts Third positions. See Sullivan v. Burkin, 460 N.E.2d 572 (Mass. 1984) (spousal share rule prospective); State Street Bank \& Trust Co. v. Reiser, 389 N.E.2d 768 (Mass. App. Ct. 1979) (creditors of settlor's estate).

50. TRUSTS THIRD, supra note 2, \$25(2).

51. See Trusts THIRD, supra note 2 , $\$ 25 \mathrm{cmt}$. e; see also PROPERTY THIRD, supra note 12 , $\S \S$ $4.1 \mathrm{cmt}$. p, $5.5 \mathrm{cmt}$. p; UnIF. Probate CoDe \$ 2-804; cf. Wasserman v. Cohen, 606 N.E.2d 901 (Mass. 1993) (applying doctrine of ademption to a revocable trust); UNIF. PROBATE CODE \$§ 2-706; 2-707 (1990).

52. See Trusts THIRD, supra note $2, \S 25$ illus. 12 (on limits per "applicant" in statutes granting public privileges or benefits); see also University Nat'1 Bank v. Harsh, 833 P.2d 846 (Colo. Ct. App. 1992) (homestead exemption available for debtor's residence held in his or her revocable trust). This should also mean that, while the trust is revocable, a nonsettlor beneficiary's creditors cannot reach his or her interest. See Trusts ThIRD, supra note 2, $\$ \$ 25 \mathrm{cmts}$. a, e, $56 \mathrm{cmt}$. b. 
objectionable include not only those that encourage divorce, or criminal or tortious conduct, but also those that are likely to interfere with other important personal or family relationships, and some forms of intrusion upon choice of career or religion. Objectionable conditions may also include restraints that tend to interfere significantly with the beneficiary's freedom to marry or even (contrary to traditional authority) freedom to obtain a divorce, which carries the risk of creating a financial dependency upon an abusive or otherwise undesirable relationship. Furthermore, provisions that serve capricious purposes (for example, unwarranted destruction of valuable assets, or other wasteful or frivolous activity) or that undermine sound administration of the trust (such as attempts to immunize trustees from removal or fiduciary accountability) may be held invalid.

The above rules limiting dead-hand control, however, recognize reasonable concerns a settlor may have in matters relating to protection of the beneficiaries' interests or of the trust property or purposes. Therefore, these rules also recognize a court's equitable discretion in appropriate cases to reform objectionable provisions to accommodate such settlor concerns in an unobjectionable manner. Thus, as in the underlying rationale for these rules themselves, the nature and implementation of doctrine in this area properly involves a balancing of societal and individual advantages that ensue from tailored freedom of disposition against other social values, and the effects on the subsequent conduct or personal freedoms of others. Even the potential burdens a former owner's unrestrained dispositions might place on courts to interpret and enforce individualized interests and conditions are relevant considerations in these cases.

The principles of Trusts Third section 29(b) do not apply to outright dispositions conditioned on whether a divorce, marriage, or other conduct occurs prior to the death of the testator or before the time at which a revocable trust becomes irrevocable. ${ }^{53}$

Some personal relationships or freedoms protected by the policies considered here may reflect fundamental values or rights (such as religious freedom) of types that may also be protected in some manner by federal or state constitutions or statutes. ${ }^{54}$ Trusts Third section 29 (b), however, involves rules and policies of the trust law and limits trust purposes and terms in ways that are not necessarily based on constitutional or statutory safeguards..$^{55}$

53. See also Restatement (SECOND) OF PROPERTY: Donative Transfers $§ 6.1 \mathrm{cmt}$. c (1983). Although the Property Second rules on behavioral restraints apply to nontrust as well as trust dispositions in various forms, those rules also address only restraints on "future conduct."

54. See, e.g., the post-Civil War provision in 42 U.S.C. \$ 1981 (1998).

55. Romanian Man's Will Orders Wife to Smoke, S.F. Chron., Sept. 20, 1993, at B1, reports: "Bucharest, Romania-A man who was nagged by his wife to stop smoking has left her everything-but only if she takes up his habit as punishment for 40 years of 'hell,' newspapers reportcd 


\section{Rule Against Perpetuities and Related Doctrine}

The most obvious of policy limits on dead-hand control are rules directly or indirectly regulating the duration of that control: rules regulating perpetuities. In nearly all states, modernization and reform activity in recent decades has gone a long way to remove or greatly curtail the unnecessarily destructive features of perpetuities rules. The Uniform Statutory Rule Against Perpetuities (USRAP) has been particularly influential. In addition to providing for the reformation of offending interests, USRAP offers a ninety-year alternative to the traditional lives in being and twentyone years. ${ }^{56}$

A couple of states have also recently increased the traditional twentyone-year period in gross. ${ }^{57}$ More recent and extreme-and of dubious merit-are statutes in several states abolishing the rule against perpetuities as part of an effort to attract trust business from elsewhere by enhancing certain tax-motivated arrangenients. ${ }^{58}$

\section{E. Restraining Voluntary and Involuntary Alienation: Spendthrift and Discretionary Trusts}

\section{Spendthrift Trusts}

Nearly all jurisdictions in the United States, unlike England, permit voluntary and involuntary restraints on the alienation of interests of trust beneficiaries in at least some manner and within some limits. ${ }^{59}$ Both the inherent limitations of spendthrift protections and the exceptions to those protections lead to the frequent use of "protective" provisions of types that are apparently even more common in England. ${ }^{60}$ Protective provisions in this country are approved in Trusts Third section 57 (and reporter's Notes thereto), allowing interests (other than retained interests of settlors) to terminate upon attempted alienation or insolvency, with replacement by broadly discretionary interests for the beneficiary and often his or her

Saturday .... The report did not specify [whether] the cause of Cemenescu's death ... was related to his smoking."

56. See Uniform Statutory Rule Against Perpetiuties § 1(a)(2) (1990). See also earlier provisions in Restatement (Second) of Property: Donative Transfers $\$ 1.4$ (1983) (on waitand-see); and $i d . \S 1.5$ (on reformation).

57. See IDaho CodE $§ 55-11$ (1997) (25 years); Wis. STat. ANN. § 700.16 (West Supp. 1997) (30 years).

58. See, e.g., Douglas J. Blattmachr \& Richard W. Hompesch II, Alaska v. Delaware, Heavyweight Competition in New Trust Laws, 12 ProB. \& PROP. 32 (1998) (discussing how the statutes have the effect of allowing unlimited life for trusts that are exempt under the generation-skipping transfer tax). The asset-protection aspect of these statutes is discussed in the last paragraph of infra Part IV.E.2. Most recently, see Ohio legislation discussed in Craig F. Frederickson, The Dynasty Trust is Here! , Prob. L.J. of OHIo, Jan.-Feb. 1999, at 41.

59. See TRUSTs THIRD, supra note $2, \S 58 \mathrm{cmt}$. a, reporter's notes.

60. In fact, on the latter, see the Trustee Act, 1925, 15 Geo. 5, ch. 19, § 33 (Eng.), under which "protective trusts" are regularly created simply by the use of that expression in English docunents. 
family. Trust law also allows the creation of analogous interests that are to commence after a beneficiary's discharge in bankruptcy, and the like. The most important of the "inherent limitations," and universally accepted in this country, is the principle that spendthrift protection ends upon distribution, when income or other funds are paid to the beneficiary. ${ }^{61}$

There appears to be no foreseeable likelihood that the basic policy of tolerating spendthrift restraints will change in this country. There is, however, some continuing activity to modify or fine-tune the specifics of spendthrift trust rules in the various states, ${ }^{62}$ although one can hardly say that there is a discernible direction in this "stirring around." An almost amusing reversal of direction was the prompt 1998 legislation in Mississippi ${ }^{63}$ to overturn the widely acclaimed Sligh v. First National Bank. ${ }^{64}$ Sligh had introduced a policy-based spendthrift exception for the benefit of victims of a beneficiary's gross negligence or recklessness. Furthermore, lengthy and vigorous debates in the last few years have eventually led to no significant changes or trends in rules identifying privileged claimants who can penetrate the spendthrift shield. ${ }^{65}$ This is particularly so with reference to privileged status that applies to certain governmental claimants, and often applies to alimony and the support claims of children and spouses and to certain claims for necessities and for protection of a beneficiary's trust interest. ${ }^{66}$

Spendthrift protections do not validly apply to interests retained by settlors. ${ }^{67}$ It is worth observing therefore that various modern developments in the use and design of trusts have required considerable elaboration and refinement of rules to determine when a beneficiary is, or may become, a "settlor." These developments have been stimulated primarily by tax planning, with the widespread use of powers of appointment, powers of withdrawal, and beneficiaries as trustees or cotrustees. Prime examples of trust "contributions" by beneficiaries are those that result from lapses of presently exercisable general powers or other rights to receive trust property. ${ }^{68}$ Analogous problems and developments arise from modern planning techniques because of the traditional rule that spendthrift protections are not

61. See Trusts THIRD, supra note $2, \S 58 \mathrm{cmt}$. d.

62. See generally GeORge G. Bogert \& George T. Bogert, The LAw of Trusts and Trustees $401-46$ (rev. 2d ed. 1992 with 1998 supp.) (reviewing in detail "Spendthrift Trusts in the Various States").

63. See Miss. Code AnN. \$ 91-9-503 (1999).

64. 704 So. 2d 1020 (Miss. 1997).

65. This has been particularly notable in the extensive hearings and deliberations on the Uniform Trust Code.

66. Compare UnIF. TRusT Code $\S 503$ (Discussion Draft Feb. 9, 1999), with ERwiN N. Griswold, SPENDTHRIFT, TRUSTS $\$ \$ 331-376$ (2d ed. 1947); compare TruSts ThIRD, supra note 2, $\S$ 59, with RESTATEMENT (SECOND) OF TRUSTs $§ 157$ (1959).

67. See, e.g., TRuSTs ThrRd, supra note $2, \S 58 \mathrm{cmt}$. e.

68. See id. $\$ 58 \mathrm{cmt}$. f. 
available to beneficiaries who hold presently exercisable general powers or other ownership equivalents. ${ }^{69}$

Both the Uniform Trust Code and Trusts Third adopt the apparently prevailing though not unanimous view that a spendthrift provision is valid only if it provides for restraint of both voluntary and involuntary transfer of the beneficiary's interest. ${ }^{70}$

\section{Discretionary Interests}

Considerably more needs to be done and currently is being done to understand the nature of discretionary interests and to facilitate their interpretation and drafting, ${ }^{71}$ and also to clarify their susceptibility to attachment by creditors. Much of the need for clarification and improved understanding stems from: (1) the deficiencies of traditional analyses based on an artificial, supposed distinction between "discretionary" and "support" trusts (with the unrealistic positions of Restatement (Second) of Trusts sections 154 and 155 being abandoned in Trusts Third section 60); ${ }^{72}$ and (2) the overly simplistic notion that beneficiaries of discretionary interests have no enforceable rights, so that their creditors have nothing to reach. ${ }^{73}$

Gradually the case law is exposing and beginning to deal with these generally fallacious ideas. ${ }^{74}$ The current Trusts Third project seeks to clarify and facilitate the development of the law of discretionary trusts. ${ }^{75}$ Particularly important is the treatment of modern trusts in which beneficiaries frequently serve as trustees or cotrustees or as holders of nonfiduciary powers of withdrawal, often limited for tax reasons by "objective" standards. ${ }^{76}$

69. See id. $\$ 58 \mathrm{cmt}$. b.

70. See UNIF. TRust Code $\$$ 501(a) (Discussion Draft Feb. 9, 1999); TRusts ThIRD, supra note $2, \S 58 \mathrm{cmt}$. b.

71. See infra Part VI.B.

72. Compare Restatement (SECOND) of TRusts $\$ \$ 154,155$ (1959), with Trusts ThIRD, supra note $2, \S 60$. For criticism and explanation, see TRUSTS THIRD, supra note $2, \S 60 \mathrm{cmt}$. a reporter's notes. The distinction is also rejected in UNIF. Trust CodE $\S 504$ (Discussion Draft Feb. 9, 1999).

73. See the inconsistency between RESTATEMENT (SECOND) OF TruSTS $\S 155 \mathrm{cmt}$. b (1959) and that Restatement's own more sound section 187 on remedying abuse of discretion. See also the more current analysis of abuse of discretion discussed in infra Part VI.B. Cf. Goforth v. Gee, 975 S.W.2d 448,450 (Ky. 1998) (allowing creditors to reach, as "mandatory," a discretionary interest entitling the beneficiary to payments to maintain her "in accordance with her station in life").

74. See TRuSTs THIRD, supra note $2, \S 60 \mathrm{cmts}$. e \& g, reporter's notes; id. $\S 50$ reporter's notes.

75. See Trusts ThIRD, supra note $2, \S 50$; id $\$ 50$ cmts. b \& c (on judicial review of trustees' exercise of discretion, and on the effects and limits of grants of "absolute" discretion); id. $\$ 50 \mathrm{cmt}$. $\mathrm{d}$ (on the meaning of standards commonly used by settlors); id. $\$ 50 \mathrm{cmt}$. e (on the significance of beneficiaries' other resources, including others' duties of support and the availability of need-based public benefit programs, such as Medicaid); id. $\$ 50 \mathrm{cmt}$. $\mathrm{f}$ (on the rights and presumptive priorities among multiple individuals and classes as concurrent beneficiaries).

76. See id. $\$ 60 \mathrm{cmt}$. $\mathrm{g}$. 
Several states have recently enacted legislation ${ }^{77}$ abandoning the traditional rule that allows a settlor's creditor to reach the maximum amount the settlor with a retained discretionary interest might receive in the proper exercise of the trustee's discretion. ${ }^{78}$ One might reasonably hope that this type of legislation will not spread much further, but one dares not underestimate the business protection/attraction incentives involved and the lobbying effectiveness of bankers associations as the perceived threat from offshore havens is joined by a threat from new onshore competitors.

\section{F. Softening of the Definite Beneficiary Requirement}

Traditional American doctrine is rooted in England's so-called "beneficiary principle." That principle provides that

courts of equity will not recognize as valid any trust which they cannot properly administer ... [sometimes] stated as, "There must be somebody in whose favour the court can decree performance" or [that] "... there being here no cestui que trust the gift must fail." A settlor as such has no locus standi to enforce the terms of his trust or gift. It follows [also] that a trust for purposes (other than charitable purposes when the Attorney-General can sue...) is invalid... ${ }^{79}$

The family and societal advantages that have justified the common law's unique acceptance of the trust concept as a vehicle of dead-hand control have resulted in a widespread insistence, in the United States as well as in England, that trusts serve either charitable or private purposes. The latter requires that there be "definite beneficiaries" to enforce the fiduciary duties of the intended trustee. Traditionally, and generally today, the requirement of definite beneficiaries can be met not only by reasonably definite classes of beneficiaries but also by beneficiaries who will become identifiable from the terms of the trust within the mandates of the rule against perpetuities. Examples of dispositions that are objectionable under the beneficiary principle are intended trusts: (1) for "friends and relatives" or for friends and relatives to be selected by the intended trustee; (2) for "such benevolent, charitable or noncharitable, purposes as my trustee may select"; and (3) for pets, monuments and other more-or-less worthy, noncapricious purposes that fall short of charity, which have nevertheless been given limited effect in some states as "honorary trusts."

77. See, e.g., Blattmachr \& Hompesch II, supra note 58; see also supra Part IV.D (discussing the perpetuities features of these statutes).

78. See, e.g., Shurley v. Texas Commerce Bank (In re Shurley), 115 F.3d 333 (5th Cir. 1997); see also TRusts THIRD, supra note $2, \S 60 \mathrm{cmt}$. f; RESTATEMENT (SECOND) OF TRUSTs $§ 156$ (1959).

79. David J. Hayton, Hayton \& Marshall: Cases and Commentary on the Law of TRusts 185 (9th ed. 1991) (citations omitted).

80. The universality -if occasional extravagance-of testators' wishes to provide for their pets is illustrated by a will reported in Farm Dogs Lose Big Inheritance, AP, Mar. 19, 1999, available in 1999 
Both Trusts Third and a modest trend in case law and legislation show a growing willingness to give some effect to traditionally invalid attempts to create trusts for persons to be selected from an indefinite class of beneficiaries, ${ }^{81}$ or for either specific or trustee-selected noncharitable purposes. ${ }^{82}$ Thus, although recognizing both dead-hand policy limitations and practical enforcement concerns, the trust law has begun to reject the notion that "because we can't force you to do it, we can't allow you to do it." (This seems a fair paraphrase of the message sent by Morice $v$. Bishop of Durham $^{83}$ to the willing legatee in that influential English classic almost two centuries ago.)

Under Trusts Third sections 46 and 47, intended trusts (or intended mandatory provisions of otherwise valid trusts) that cannot be enforced as such may be allowed as "adapted trusts." That is, the intended purpose may be carried out, within reasonable time limits (normally limited to a twentyone-year period derived, by analogy, from the rule against perpetuities' twenty-one-year period in gross), if the devisee or legatee will do so by exercising a nonmandatory, generally personal "power" to appoint or expend (to or for the members of an indefinite class or the noncharitable purpose) funds that are otherwise held in trust for distribution in default of appointment to beneficiaries implied by law-that is, for the testator's successors in interest, or for the other beneficiaries of an otherwise enforceable trust. Thus, the adapted trust is a true trust that is enforceable by the reversionary beneficiaries, subject to the trustee's power of distribution (not mandatory as intended, but analogous to a power of appointment). As adapted in this fashion, the trust avoids the complete failure of the decedent's purpose that would occur under traditional doctrine, which has simply required the devisee to hold immediately on resulting trust. ${ }^{84}$

Trusts Third section 46(2) further explains how the adapted trusts would operate for intended trusts for "friends and relatives" to be selected by an intended trustee. ${ }^{85}$ Adaptation of an intended trust for "such benevolent, charitable or noncharitable, purposes as my trustee shall select" is discussed in Trusts Third section $47(1),{ }^{86}$ which offers a better

WL 14512668, under dateline from Wellington, New Zealand. There, the court held a bequest of $\$ 530,000$ wholly invalid ("even for the most aristocratically raised dogs") in an apparent application of traditional doctrine.

81. See TRUSTS THIRD, supra note $2, \S 46 \&$ reporter's notes.

82. See id. § 47 \& reporter's notes.

83. 32 Eng. Rep. 947 (Ch. 1805).

84. With the adapted trusts in TRusts THIRD, supra note $2, \S \S 46-47$, compare Leach v. Hyatt, 423 S.E.2d 165 (Va. 1992). See also England's apparent change of course in Baden v. Smith, 2 All E.R. 1304 (1972); McPhail v. Doulton, 2 All E.R. 228 (1970).

85. See also Trusts THIRD, supra note $2, \S 46(2) \mathrm{cmts}$. $c-g$; $c f$. UNIF. TRUST CODE $\$$ 402(b) (Discussion Draft Feb. 9, 1999).

86. TRUSTs THIRD, supra note $2, \S 47(1)$; see also UNIF. TRUST CODE $§ 406(a)$ (Discussion Draft Feb. 9, 1999). 
result for the type of intention that failed completely in Morice v. Bishop of Durham. Trusts Third section 47(2) describes the adapted trust's application to what have been called "honorary trusts" for pets, monuments, and other worthy purposes that do not qualify as charitable, and Uniform Probate Code section 2-907(b) offers a slightly different legislative treatment.

\section{$\mathrm{V}$ \\ Revocation, Termination, and Modification of Trusts}

\section{A. Settlor's Powers to Revoke and Amend}

\section{Settlor's Implied Power to Revoke}

Like general doctrine applicable to inter vivos gifts, under the common law of trusts the settlor has no power to revoke or amend an inter vivos trust except as authority to do so is reserved in the terms of the trust. The beginmings of a legislative trend-which can be expected to grow-is the enactment of statutory rules in a couple of states (like the long-standing California statutes ${ }^{87}$ declaring essentially that "[u]nless the terms of a trust expressly provide that the trust is irrevocable, the settlor may revoke or modify the trust." ${ }^{88}$ The Uniform Trust Code proposal just quoted has drawn surprising support (with a single dissent) from the NCCUSL drafting committee and advisers.

\section{Exercise of Power to Revoke or Amend}

Other features of the Umiform Trust Code section 602 also offer useful clarification and some liberalization with respect to several matters involving the manner of revocation. Section 602(c) proposes that

[a] trust that is revocable by the settlor may be revoked or modified: (1) by substantially complying with the method specified by the ternis of the trust; or (2) unless the terms of the trust expressly make the specified method exclusive, by $a$ will or any other method manifesting clear and convincing evidence of the settlor's intent. ${ }^{89}$

Section 602(b) proposes a provision stating:

If the trust is created or funded by more than one settlor: (1) to the extent the trust consists of community property, the trust may be revoked by either spouse acting alone ${ }^{90}$ but may be modified only by joint action of both spouses; [and] (2) to the extent the trust consists of other property, each settlor may revoke or modify the

87. See Cal. Prob. Code $§ 15400$ (West 1998).

88. UNIF. TRUST CODE $§ 602$ (a) \& cmt. (Discussion Draft Feb. 9, 1999).

89. Id. § 602(c) (emphasis added).

90. The intended result here is that the trustee is to return the property to both spouses as their community property, as will be explained in a part of $i d . \S 602(\mathrm{~d})$ that is presently being redrafted. 
trust as to the portion of the trust property attributed to that settlor's contribution..$^{91}$

Revocation and amendment are further addressed in another Uniform Trust Code draft subsection. Section 602(e) provides that a settlor's "powers with respect to revocation or modification may be exercised by an agent under a power of attorney only to the extent the terms of the trust or the power of attorney so authorize. ${ }^{.92}$ Section 602 (f) adds that a conservator or local equivalent "may revoke or modify a revocable trust with the approval of the court supervising the [conservatorship]," except that a general provision of the Uniform Trust Code (section 104) allows, as stated in the comment to section 602, "a settlor to direct in the terms of the trust that this [rule] not apply." ${ }^{33}$ Such a prohibition, however, would "not mean that the conservator is prohibited from taking appropriate action to protect the settlor's interest if the settlor, now under conservatorship, is also a beneficiary of the trust." removal of the trustee [or] . . to enforce the trust according to its terms." 95 An additional provision may be needed in the Act to make clear that a conservator (or equivalent) niay in any event exercise the settlor's power of revocation to the limited extent necessary to meet current needs of the settlor and his or her dependents, for the rare case in which the trust does not provide this protection but relies on the settlor's power to supply it.

\section{B. Beneficiary Power and Judicial Authority to Terminate or Modify a Trust}

A modern trend in American law is to liberalize rules governing the termination and modification of trusts by agreement of the beneficiaries or by the exercise of judicial authority.

In most American states, however, there is yet no counterpart of England's Variation of Trusts Act $1958 .{ }^{96}$ Conversely, England does not recognize ${ }^{97}$ a rule like the Claflin doctrine, ${ }^{98}$ which is discussed immediately below and is generally accepted throughout the United States. ${ }^{99}$

\footnotetext{
91. Id. $\S 602(\mathrm{~b})$.

92. Id. $\S 602(\mathrm{e})$.

93. Id. $\S 602(\mathrm{f}) \& \mathrm{cmt}$

94. Id. $\S 602 \mathrm{cmt}$.

95. Id.

96. 6 \& 7 Eliz. 2, ch. 53. But see Mo. Rev. Stat. $\$ 456.590 .2$ (1992) (enacted in 1986).

97. See Saunders v. Vautier, 4 Beav. 115 (Ch. 1841), aff'd, 41 Eng. Rep. 482 (1841).

98. See Claflin v. Claflin, 20 N.E. 454 (Mass. 1889).

99. But see Hammerstrom v. Commerce Bank, 805 S.W.2d 434 (Mo. Ct. App. 1991), decided under the Missouri statute cited in supra note 96.
} 


\section{Modification or Termination by Consent of the Beneficiaries}

The law of most American jurisdictions on termination and modification by consent of the beneficiaries can be briefly summarized. A trust may be modified or prematurely terminated by the unanimous action of all beneficiaries, provided that to do so will not interfere with a "material purpose" of the settlor unless the settlor is alive and consents. ${ }^{100}$ (The proviso here is the Claflin doctrine. $)^{101}$

Two visible, but so far modest, tendencies on this matter are worth mention. The first is to allow some form of vicarious consent to be given, by guardian ad litem ${ }^{102}$ or virtual representation, ${ }^{103}$ on behalf of unborn or unascertainable beneficiaries. A number of statutes and legislative proposals illustrate this trend. ${ }^{104}$ Without some form of vicarious representation, the consent of all beneficiaries could never be obtained in typical trusts, such as one for $X$ for life, remainder to $X$ 's issue living at her death. ${ }^{105}$ The second trend in beneficiary modification is to attempt to clarify ${ }^{106}$ the material purpose qualification (the Claflin doctrine), and perhaps to provide some additional flexibility in it. ${ }^{107}$

\section{Judicial Power: "Equitable Deviation"}

In the absence of the beneficiaries' consent, the common law authority of courts is narrowly limited and can be simply stated with reasonable accuracy for nearly all jurisdictions. A court may authorize deviation from the administrative terms of the trust if, by reason of changed circumstances not contemplated by the settlor, adherence to those terms would prevent or

100. See generally 4 Austin Wakeman Scott \& William Franklin Fratcher, The Law of TRUSTs $\$ \S 337-340.2$ (4th ed. 1989).

101. See Claflin, 20 N.E. at 454.

102. See Hatch v. Riggs Nat'1 Bank, 361 F.2d 559 (D.C. Cir. 1966).

103. See Estate of Lange, 383 A.2d 1130 (N.J. 1978).

104. See Unif. Probate Code $\S 1-403$ (1990); Cal. Prob. Code $\S 15405$ (West 1998) (guardian ad litem may give eonsent based on "general family benefit"); see also UNIF. TRUST CoDE $\$ \S 301-309$, 408 (Discussion Draft Feb. 9, 1999); Eun C. Han, Premature Termination of Non-Spendthrift Trusts: Reconciling a Dead Settlor's Intent With a Living Beneficiary's Needs, 3 TEX. WESLEYAN L. REv. 191, 206-07 (1996).

105. See, e.g., In re Lewis' Estate, 79 A. 921 (Pa. 1911); see also Levy v. Crocker-Citizens Nat'1 Bank, 14 Cal. App. 3d 102 (Ct. App. 1971) (despite request of settlor who held testamentary general power of appointment over the interests of the unborn potential beneficiaries).

106. See Rust v. Rust, 176 F.2d 66, 67 (D.C. Cir. 1949) (distinguishing "material purpose" from mere "intent").

107. See, e.g., Calif. Prob. Code $\S 15403$ (b) (West 1998) (finding that judicial discretion, in effect, to waive settlor's material purpose); see also RESTATEMENT (SECOND) OF TRUSTs $\$ 337 \mathrm{cmt}$. $\mathrm{f}$ (1959) (noting that mere provision for enjoyment by successive beneficiaries does not constitute a material purpose that would prevent termination by consent); UNIF. TRUST CODE $\S 408$ (a) (Discussion Draft Feb. 9, 1999) (finding that mere inclusion of a spendthrift provision "not prcsumed to constitute a material purpose of the settlor"). 
jeopardize fulfillment of a trust purpose. ${ }^{108}$ The standard is less severe when mere division of a trust or a combining of trusts is sought. ${ }^{109}$

Again, there is a modest or beginning trend to liberalize the above rule, as long as the settlor's objectives and probable intentions are respected. Expected liberalization is the result of two concerns: (1) that the standard involved, essentially one of emergency, may be unnecessarily and undesirably demanding; ${ }^{110}$ and (2) that confining equitable deviation to administrative provisions may be too narrow because the need to cure inadequate foresight in drafting sometimes extends to distributive details. ${ }^{11}$

There is also some thought that it should be sufficient that the troublesome circumstances were unanticipated by the settlor, even where the circumstances have not actually changed, ${ }^{112}$ analogizing ${ }^{113}$ this softened rule to liberalized mistake doctrine. ${ }^{114}$

\section{Charitable Trusts: The Cy Pres Doctrine}

The law concerning modification of charitable trusts under the cy pres doctrine is also a subject of some limited concern, ${ }^{115}$ but it would be overstating the case to say that significant developments have occurred to date. ${ }^{116}$ Nevertheless, the doctrine has received some attention in the development of the proposed Uniform Trust Code; attention will also be given to two concerns as the American Law Institute's Trusts Third project proceeds.

Experience suggests that some clarification would be useful with respect to how, in the initial requirement for the application of cy pres,

108. See 2a Austin Wakeman Scott \& William Franklin Fratcher, The LaW of Trusts $\S \S 167-167.2$ (4th ed. 1987); cf. id. §§ 168, 335-336.

109. Quick, easy "splitting" by a trustee without court authorization became particularly important with the 1986 version of the generation-skipping transfer tax in Internal Revenue Code chapter 13. See, e.g., BankBoston v. Marlow, 701 N.E.2d 304 (Mass. 1998); UNIF. TrusT CodE $\S 413$ (Discussion Draft Feb. 9, 1999) (on combining and dividing trusts).

110. See, e.g., Bank of Delaware v. Clark, 249 A.2d 442 (Del. Ch. 1968) (adopting a more lenient "substitution of judgment approach"); UN1F. TRUST CoDE § 409(a) (Discussion Draft Feb. 9, 1999) (enabling judicial action if deviation "will substantially further the settlor's purposes in creating the trust").

111. See, e.g., CAL. Prob. Code $\$ 15409$ (a) (West 1998) (which applies to "dispositive" as well as administrative provisions); see also UN1F. TRUST CODE \$ 409(a) (Discussion Draft Feb. 9, 1999) (proposing that the court's authority apply to "administrative or dispositive terms"); $c f$. Mo. REv. STAT. $\S 456.590 .20$ (1992).

112. See UNIF. TRUST CODE $\$$ 409(a) (Discussion Draft Feb. 9, 1999).

113. See id. $\$ 409$ (a) cmt.

114. See supra Part III.C.

115. See, e.g., Roger Sisson, Comment, Relaxing the Dead Hand's Grip: Charitable Efficiency and the Doctrine of Cy Pres, 74 VA. L. REv. 635 (1988).

116. But see MiNN. STaT. ANN. § 501.12(3) (West 1990) (softening the initial requireinent of the doctrine (discussed infra in text accompanying notes 117-18) to "impracticable, inexpedient, or impossible"); WIS. STAT. ANN. $§ 701.10$ (West Supp. 1998). 
such traditional terms as "impossible or impracticable" 117 might be applied to the increasingly frequent problem of trust funds that have become excessive for their stated charitable purposes. The term "wasteful" might be appropriate to describe the point at which some of the trust's funds should cease to be expended for the particular purpose stated by the settlor and be diverted cy pres to another, even though the original charitable purpose could in fact, even if not with significant public benefit, absorb more expenditures. Accordingly, the Uniform Trust Code would add the term "wasteful" to this first requirement for the exercise of cy pres. ${ }^{118}$ The same word can be expected to be used in Trusts Third when the project reaches this matter.

More fundamental is the increasing doubt among reformers and their advisers about the need or duration of the traditional requirement that a "general charitable purpose" be found in order to apply the cy pres doctrine. Absent that finding, the property reverts to the successors in interest of the settlor, who is usually long deceased when the issue arises. A "general charitable purpose" is an underlying purpose broader than the settlor's stated purpose(s). ${ }^{119}$ Uniform Trust Code section 408(b)(2) would simply do away with the general charitable purpose requirement and with the possibility that the property might revert. Trusts Third is likely to settle for introducing an explicit presumption against the resulting trust, with the presumption to become increasingly difficult to rebut as time passes and possibly conclusive after twenty-one years. ${ }^{120}$

\section{VI}

\section{Clarifying and Modernizing Significant Rules of Construction}

\section{A. Remainders and Other Future Interest Problems}

In recent years, legal scholarship, judicial opinions and particularly legislation have sought to refine rules of construction in our most troublesome areas of recurring uncertainties of meaning. These efforts seek better to ascertain the probable intentions of transferors-or more precisely to attribute intentions to transferors who (or whose counsel) have failed to consider these matters, or at least failed to address them in the instrument or otherwise to leave evidence of an actual intention that could be discovered through the process of interpretation.

117. RESTATEMENT (SECOND) OF TRUSTS \$ 399 (1959).

118. UNIF. TRust CODE $\$ 408(b)$ (Discussion Draft Fcb. 9, 1999).

119. See, e.g., RESTATEMENT (SECOND) OF TRusts $§ 399$ (1959); see also id. $\$ 400$ (regarding purposes that have been "fully accomplished without exhausting the trust property").

120. The twenty-one-year period is derived, by analogy, from the perpetuities period without measuring lives, even though reversionary interests are not actually subjcct to the common law rulc against perpetuities. 


\section{Survivorship Requirements}

One area where considerable progress can be recognized is in the matter of whether a condition should be implied requiring remainder beneficiaries to survive life beneficiaries, or until some other time of distribution. With better understanding of the issues and considerations involved, judicial decisions have shown considerable improvement in recent decades. With the further possibility of broader alternatives, however, significant changes are being advanced through legislation.

Reasonably revealing, and representative of a broad array of recurring situation-types, are simplified dispositions in trust: (1) "for $\mathrm{L}$ for life, remainder to her children;" and (2) "for L for life, remainder to his issue." Question: Are L's "children" or "issue" impliedly required to be alive at L's death for their interests to take effect? In both of these situations substantial estate planning considerations, both tax and nontax, virtually mandate that an informed drafter require class members to survive until L's death.

It would seein proper for courts to take account of this factor-that is, of what sound planming calls for. Cases have therefore recognized that in situation 2 it is appropriate to imply a survival requirement with respect to the class of "issue" (or, similarly, for a class of "descendants"). ${ }^{121}$ On the other hand, courts have properly been unwilling to imply such a requirement with respect to "children" (or other inflexible, one-generation classes) in cases like situation 1 . This is because of an overriding concern that to do so would do even greater harm than good to the transferor's overall objectives by risking the exclusion of natural objects of his or her bounty, usually the descendants (or other family members) of a child who fails to survive, a risk that does not exist when a settlor uses the flexible term "issue" or "descendants.".22

The dilemma in cases of these single-generation classes (and in the case of named individuals, as in a disposition "for $L$ for life, remainder equally to $R 1, R 2$, and $R 3^{\prime \prime}$ ) arises from the standard common law approach: A court is permitted to choose only between the two constructions that it is perceived the language will allow-that "children" or the like means either all of the children (i.e., including the estates of deceased children whether or not they leave issue) or only the children who survive $L$. The court must therefore choose the least damaging of these unfortunate

121. Some years ago (while most courts were still struggling with irrelevancies such as whether gifts were to a "class" or were "vested or contingent"), Altman v. Rider, 291 S.W.2d 577 (Ky. App. 1956), properly reached the conclusion stated above in the text, "without becoming involved in the intricacies of the law of property," by "merely attempt[ing] to project what the testator expected to happen." Id. at 579.

122. An opinion that was insightful on this critical matter of balancing the relevant considerations, but that nevertheless illustrates unfortunate dicta of the type noted parenthetically in supra note 121 is Coddington v. Stone, 9 S.E.2d 420 (N.C. 1940) (passim). 
alternatives, rationalizing essentially that "a court cannot write a will or trust provision" for a settlor who failed to provide for the issue of a deceased child or who, if asked, might have preferred to give a deceased child a power of appointment by which to provide more flexibly for his or her family. As judicial decisions have recognized the real considerations appropriate to their limited choices, they have at least come to provide greater certainty, and somewhat more suitability, of result, rather than continuing to fumble with such terminology as "vested" or "contingent" or inquiring whether the remainder beneficiaries are a "class" or a group of named beneficiaries.

In recent years, however, legislation has opened up a considerably better alternative. This alternative is sometimes based on analogy to antilapse statutes that apply to related beneficiaries who predecease a testator and generally supply an implied gift to a deceased child's issue (if any)issue who may be the settlor's grandchildren where $L$ was the settlor's spouse, or the settlor's great-grandchildren where $L$ is the settlor's child. The trend, and most of what recent legislation exists, is based on 1990 amendments to Uniform Probate Code section 2-707. ${ }^{123}$

\section{Definitional Problems in Class Gifts}

Several important constructional issues involving remainders to classes have been brought under the microscope in recent years, and progress is definitely being made, but it would be an exaggeration to suggest that the issues have become settled by generally accepted solutions.

\section{a. Descendants' Shares}

One set of issues involves the shares in which distribution is to be made to "descendants" or "issue," and the like. ${ }^{124}$ Construction generally, though not necessarily, follows local intestacy principles. As a result: (1) strict per capita distribution among issue has essentially been abandoned; ${ }^{125}$ (2) strict per stirpes (beginning with the generation immediately below the common ancestor, whether or not there are living members of that generation) is greatly diminishing in popularity; (3) a modernized per stirpes (or taking "by right of representation" with the representation beginning with equal division in the nearest descendant

123. These changes and relevant authorities are discussed in Lawrence W. Waggoner, The Uniform Probate Code Extends Antilapse-type Protection to Poorly Drafted Trusts, 94 Mich. L. REv. 2309 (1996), and more broadly in Edward C. Halbach, Jr. \& Lawrence W. Waggoner, The UPC's New Survivorship and Antilapse Provisions, 55 AlB. L. Rev, 1091 (1992) (Symposium on 1990 Revised Uniform Probate Code).

124. See Property THIRD, supra note $12, \S 2.3$ \& reporter's notes.

125. See Edward C. Halbach, Jr., Stare Decisis and Rules of Construction in Wills and Trusts, 52 CALIF. L. REv. 921, 926-30 (1964) for a case study recounting New York's agonizing but revealing experience with this antiquated rule of construction. 
generation in which there are living members (the "stock" generation) with representation thereafter for deceased inembers' issue) has come to be the prevalent current view, with reinforcenent from the original (1969) Uniform Probate Code; and now (4) a halting emergence of a tendency to adopt the revised Uniform Probate Code's regime of per capita at each generation (or "per capita with per capita representation").

\section{b. Status of Adoptees}

Although to a lesser degree than in the case of intestacy statutes (for somewhat understandable reasons), the gradual but clear-cut tendency is to treat adoptees as members of the adoptive family for purposes of class gifts, thereby rejecting the traditional, so-called "stranger to the adoption rule." There is, however, solne increasing recognition of the need to provide a form of protection against manipulative (what some have inadequately termed "adult") adoptions. There is also widespread recognition that persons adopted "out" generally should not be included in gifts to the natural family. There is, however, a beginning recognition that this general policy cries out for some exceptions for persons adopted out after they have taken root in the natural family (for example, following the death of a parent who was a member of that family). ${ }^{126}$

\section{c. Status of Nonmarital Children}

The struggle to deal properly with issues of this type is hardly new, but present trends cannot yet be said to represent a solid consensus. Nor has there been a widespread effort to reconcile hazy U.S. Supreme Court cases on constitutional mandates ${ }^{127}$ with at least arguably appropriate state policies, especially those designed to reflect probabilities of transferor intentions. ${ }^{128}$ One clearly recognizable tendency is to treat children born out of wedlock as niembers of the families of their natural parents in the absence of adoption. This is especially so in legislation dealing with intestate succession, from which class gift constructions are often derived. There inay be some need here for a cautiously designed "stranger to the conception rule," and for special rules to deal with cases of a decedent who rejected or is unaware of the child. It should be noted that these issues, like class gift matters involving children by any defmition, do not involve questions of forced heirship, support obligations, or public entitleinents.

126. For a discussion of Uniform Probate Code provisions, other legislation, and case law involving parent-child relationships in this context (adoption) and involving nonmarital children (text immediately below), see PROPERTY THIRD, supra note $12, \S 2.5$ reporter's notes.

127. Compare Lalli v. Lalli, 439 U.S. 259 (1978), with Trimble v. Gordon, 430 U.S. 762 (1977). See also Reed v. Cainpbell, 476 U.S. 859 (1986).

128. Compare Hietala v. Pakarinen, 178 N.W.2d 714, 717-18 (Minn. 1970), with Estate of Dulles, 431 A.2d 208 (Pa. 1981). 


\section{Rejection of the Doctrine of Cross Remainders}

Surprisingly common are cases in which property is left in trust, for example, "to pay the income equally to my daughter $D$ and my son $S$, remainder on the death of the survivor to my issue who are then living." The problem arises when $D$ dies while $S$ is still alive, and the stated remainder is thus not ready to take effect. What is to be done with the "share" of income that $D$ had been receiving? The traditional majority view has been that this ( $D$ 's) "share" goes to $S$, thus giving him all of the income for the rest of his lifetime (the doctrine of "cross-remainders" in income).

The primary alternatives to the cross-remainders construction are: (1) that the "share" of $D$ for the remaining duration of the trust was undisposed by the testator (settlor) and thus becomes intestate ("resulting trust") property; (2) that the income from $D$ 's "share" is to be accumulated for eventual distribution as a part of the trust remainder; (3) that, by implication, the remainder to the issue (of both $S$ and $D$ ) accelerates so that $D$ 's "share" of income is distributed for the rest of the trust's duration to all of the settlor's descendants; or (4) that $S$ and $D$ each received income interests for the lifetime of the survivor, so that $D$ 's "share" is an asset of her estate, as a life estate pur autre vie; or (5) that there is a gift by implication merely to the issue of $D$ for as long as $S$ lives, thereby preventing a distortion in the preferred and inferred plan of equal treatment of both descending lines-the result usually drafted into such a plan by careful drafters. This last alternative is adopted (assuiming $D$ left issue) in Trusts Third section 49 , comment $c .{ }^{129}$

\section{B. Construction and Enforcement of Discretionary Interests}

The use of trust powers and the discharge of trusteeship responsibilities regularly involve the exercise of fiduciary judgment, or "discretion," with which courts generally do not interfere except to prevent abuse or the imsinterpretation of trust provisions. ${ }^{130}$

The growing use and variety of discretionary trusts-or inore properly, trusts that grant the trustee discretion with respect to soine or all of the distributions that one or more of the beneficiaries are to receive-give rise to increasingly common and increasingly diverse issues about discretionary powers and benefits. Such discretion may relate to invasion of principal for an income beneficiary, to distributions of incoine or principal to, or for the benefit of, either a primary beneficiary or a secondary (or lower priority) beneficiary, or to distributions that are to be sprinkled

129. This was also the result, for example, of Dewire v. Haveles, 534 N.E.2d 782 (Mass. 1989). Cf. Collier v. Napierski, 258 N.E.2d 789 (Mass. 1970) (also avoiding the cross-remainder result).

130. See generally 2 Austin Wakeman ScotT \& William Franklin Fratcher, The LaW of TRusTs §§ 128-128.7 (4th ed. 1987). 
among a class of beneficiaries, such as the settlor's surviving spouse and descendants.

Judicial opinions, practitioners and authors of articles and treatises increasingly recognize and attempt to respond to the need to provide guidance on these matters to trustees, beneficiaries, their counsel, and judges. Issues that have been helpfully addressed in recent years in cases, Trusts Third or, on some points, statutes include: (1) the presumed construction of recurring standards (for example, "support") or of discretionary powers in the absence of express standards; ${ }^{131}$ (2) whether and in what manner a trustee is to take account of a beneficiary's other resources that could be used for the settlor's intended purpose(s) ${ }^{132}$ (3) the extent to which the trustee's discretion, judicial supervision and the beneficiaries' rights of enforcement are affected by the settlor's use of such language as "sole and uncontrolled" or "absolute" discretion;; ${ }^{133}$ and (4) how all of this applies, and the priority and impartiality-related preferences to be attributed to settlors, when the discretionary power is one for multiple individuals or classes as concurrent beneficiaries. ${ }^{134}$

Statutes and decisions increasingly make clear that language such as "absolute" and the like in a grant of discretion (or that a provision under which the trustee is to determine whether a particular beneficiary is to receive anything) is not to be taken literally. Such wording does not dispense with the trustee's normal duty to act in good faith and in a manner consistent with the terms and purposes of the discretionary power. ${ }^{135}$

In addition to discussing the various presumptions (rules of construction) relating to discretionary interests and their enforcement, comment $g$ to Trusts Third section 50 suggests an appropriate approach to the interpretation process when problems of meaning arise or when it is questioned whether a given presumption is appropriate to a particular case. The rights of creditors with respect to debtors' discretionary interests are discussed in Trusts Third section 60 and above in Part IV.E.

131. See Trusts THIRD, supra note $2, \S 50 \mathrm{cmt}$. d; see also id. $\S 50 \mathrm{cmt}$. b \& cmt. d, reporter's notes (collecting authorities on this topic).

132. See id. $\S 50 \mathrm{cmt}$. e \& reporter's notes (collecting authorities on this topic). Also considered there are such matters as another's duty to support the beneficiary and, of growing importance, the potential availability of need-based public benefit programs as other "means" available to the beneficiary.

133. Id. $\$ 50 \mathrm{cmt}$. c.

134. See id. $\$ 50 \mathrm{cmt}$. f.

135. See id. $\S 50 \mathrm{cmt}$. c, reporter's notes (collecting and discussing authorities); see also UN1F. TRUST CODE $\S 814$ (Discussion Draft Feb. 9, 1999); id. $\S 801$ (on discretion more generally); $c f$. REstatement (SecoND) OF TRusts $§ 187$ \& cmts.j \& k. 


\section{VII \\ The Office of Trustee; Fiduciary Duties and Standards}

\section{A. Decision Making by Multiple Trustees}

The common law of trusts has traditionally required unanimity of action by the trustees of private trusts, while the common law of charitable trusts provides for majority rule when the charitable trust has three or more trustees. Yet even in private trusts, decision making by majority vote is provided for by the terms of many trusts and is prescribed in a few statutes as the default rule.

On the basis of the satisfactory long-term experience with the charitable trust rule, drafting tendencies of estate planners, and a modest legislative trend, Trusts Third section 39 adopts a majority-control rule for three or more trustees as the preferred common law view in the absence of contrary provision in the terms of the trust. Uniform Trust Code section 703(a)(1) apparently will also provide majority control as the statutory default rule for private as well as charitable trusts. There has been no sign whatever of opposition from advisory groups for the ALI or NCCUSL projects, or from lawyers' or bankers' organizations.

It is important to observe, however, that although majority control frequently excuses a dissenting trustee from certain liabilities, it does not excuse a dissenting or minority trustee from the normal duty to remain informed, to participate in fiduciary deliberations, and to take necessary action to enjoin or otherwise prevent a breach of trust by the majority.

\section{B. Resignation and Removal of Trustees}

Absent consent of all beneficiaries or other provision in the terms of the trust, it is generally stated that a trustee may resign only with approval of the court. Uniform Trust Code section 705(a)(3) continues this requirement, but subsection (a)(2) attempts to facilitate resignation by thirty-day notice to "qualified beneficiaries." 136 Trusts Third allows a trustee to resign, inter alia, simply "upon terms approved by a proper court." 137

Traditional principles for removal of trustees for cause have been sufficiently flexible and generally satisfactory. Thus, the Uniform Trust Code and Trusts Third attempt mainly to provide some clarification and elaboration. ${ }^{138}$ They attempt particularly to heighten sensitivity to the needs and best interests of the beneficiaries, but without disregarding the settlor's intentions and proper interests in the matter.

136. UNIF. Trust CoDE $\S 705($ a)(2) (Discussion Draft Feb. 9, 1999).

137. TRUSTS THIRD, supra note $2, \S 36$.

138. See Unif. Trust Code $\S 706 \&$ cmts. (Discussion Draft Feb. 9, 1999); Trusts ThIRD, supra note $2, \S 37$. 


\section{Compensation of Trustees}

The normal presumption in this country is that trustees of both charitable and private trusts are entitled to compensation. The widespread use of statutory fee schedules for executors and administrators generally has now been supplanted by a rule of reasonable compensation, a process accelerated by the promulgation of the Uniform Probate Code in 1969. ${ }^{139}$ The need and justification for abandoning statutory schedules in favor of conipensation that is "reasonable under the circumstances" is even stronger in the case of trustees. For example, even in some states that still provide for statutory fee schedules for personal representatives, "reasonable compensation" is provided as the statutory or common law rule for trustees in the absence of contrary provision in the terms of the trust. ${ }^{140}$ The Uniform Trust Code and Trusts Third will reinforce the present trend. ${ }^{141}$

An accompanying trend recognizes that courts have equitable authority to require departures from fee schedules prescribed either by statutes or by trust instruments when circumstances show those schedules to be distinctly excessive or inadequate. ${ }^{142}$ Greater flexibility and room for the exercise of sound discretion also need to be and are being recognized in statutes, cases, and texts with respect to: (1) the determination and compensation entitlements of multiple trustees; ${ }^{143}$ and (2) the effects on fiduciary compensation of a trustee's employment of advisers or agents. ${ }^{144}$ Arbitrary doctrine or statutory rules have often impeded the exercise of common sense in these situations. Thus, guidance is offered and the need for flexibility is emphasized by an increasing number of modern cases and legislation, as well as treatise discussions. ${ }^{145}$

\section{Delegation}

Traditionally, in the absence of a contrary trust provision, cases and treatises have grudgingly accepted delegation by trustees on a narrowly confined basis. Earlier Restatements have allowed delegation only for

139. See Unif. Probate Code § 3-719 (1990).

140. Compare CAL. Prob. CoDE $\$ 10800$ (West 1998), with id. $\$ 15681$.

141. See UNIF. TRUST CODE § 708(a) (Discussion Draft Feb. 9, 1999); TRUSTs ThIRD, supra note $2, \S 38$.

142. See TRUSTs ThIRD, supra note 2 , $\$ 38$ cmts. c \& e; UNIF. TRUST CQDE $\$ 708$ (b) (Discussion Draft Feb. 9, 1999) (referring to trustee duties that "are substantially different from those contemplated when the trust was created" and to compensation specified by the terms of the trust that "would be unreasonably low or high"); see also, e.g., 12 DeL. CoDE ANN. tit. 12, \$3560 (1995). Grimm v. Kruse, 705 N.E.2d 483, 494 (Ind. Ct. App. 1999), recently recognized courts' authority to increase compensation "if necessary under the circumstances," but declined under the facts to add to fees prescribed by the will for the executor and attorneys. Also, for an interesting case involving a trust drawn by the fiduciary, see Andrews v. Gorby, 675 A.2d 449 (Conn. 1996).

143. See, e.g., TRUsTs THIRD, supra note $2, \S 38 \mathrm{cmt}$. i.

144. See, e.g., id. $\S 38 \mathrm{cmt}$. c (especially illus. 1 ).

145. See id. $\$ 38$ reporter's notes. 
"ministerial" acts or to the extent the trustee has no reasonable alternative, ${ }^{146}$ and they had specifically forbidden delegation of the "power to select investments." 147

The prudent investor rule of Trusts Third requires only that a trustee "act with prudence in deciding whether and how to delegate authority and in the selection and supervision of agents." 148 In official commentary on investment activities, Trusts Third observes that "the trustee has power, and may sometimes have a duty, to delegate such functions and in such manner as a prudent investor would delegate under the circumstances." 149 An appendix to this volume partially and preliminarily amends the rule of prior section 171 to state: "A trustee has a duty personally to perform the responsibilities of the trusteeship except as a prudent person might delegate those responsibilities to others," adding that "[i]n deciding whether, to whom and in what manner to delegate fiduciary authority ... and thereafter in supervising agents, the trustee is under a duty... to exercise fiduciary discretion and to act as a prudent person would act in similar circumstances." ${ }^{\text {150 }}$ Amended comment $f$ of that appendix section adds:

Delegation is not limited to the performance of ministerial acts. In appropriate circumstances delegation may extend, for example, to discretionary acts, to the selection of trust investments or the management of specialized investment programs, or to other activities of administration involving significant judgment ....

$$
\ldots
$$

The trustee's exercise of this discretionary authority is judicially reviewable only for abuse, based on failure to exercise the required degree of care, skill, or caution. ${ }^{151}$

The Uniform Prudent Investor Act (discussed later in Part VIII) offers a codification (in section 9(a)) of the rule of Trusts Third with respect to delegation of investment "and management" functions. ${ }^{152}$ Section 9(c) of the Act expressly provides that a trustee who complies with the requirements of proper delegation "is not liable to the beneficiaries or to the trust for the decisions or actions of the agent to whom the function was delegated." ${ }^{153}$ Section 9(a)(1)-(3) requires prudence in selecting an agent, in establishing the scope and terms of the delegation, and in monitoring the

146. See Restatement (SECOND) OF TRUSTs § 171 (1959).

147. Id. $\$ 171 \mathrm{cmt} . \mathrm{h}$.

148. Restatement (Third) of Trusts: The Prudent lnvestor Rule $\S 227$ (c)(2) (1992) [hereinafter TRUSTS THIRD: PRUDENT INvestoR]; see also John H. Langbein, Reversing the Nondelegation Rule of Trust-Investment Law, 59 Mo. L. REv. 105 (1994).

149. TRUsts ThIRD: PRUDent INvestor, supra note $148, \S 227 \mathrm{cmt}$. j.

150. Id. $\$ 171$.

151. Id. $\$ 171 \mathrm{cmt}$. f.

152. UNIFORM PRUDENT INVESTOR ACT § 9(a) (1994).

153. Id. $\$ 9(\mathrm{c})$. 
agent's performance and compliance with the terms of the delegation. The agent, of course, is liable for violating the terms of the delegation or for other violations of the fiduciary duties of the agency.

The foregoing trends with regard to delegation of the authority of trustees apply to the employment and use of agents and do not necessarily apply to the situation-requiring much greater caution and qualificationof delegation among trustees. This matter will receive more careful examination later in the Trusts Third project, which may adhere more closely to traditionally limited bases of delegation and will caution against the dangers of supposed "delegation" being used as a means by which multiple trustees might improperly attempt to divide up the trusteeship. ${ }^{154}$

\section{E. The Duty of Loyalty}

The fundamentally important duty of loyalty provides a normally absolute prohibition against self-dealing by trustees and against a trustee's creation of (much less responding to) conflicting interests. Probably the only significant trend in this area is the creation of a few specific exceptions, the most important of which is the statutory authorization, now in nearly all states, for trust companies to participate in the establishment of proprietary mutual funds and to receive compensation for their services to those funds, even with respect to trust assets under the trust company's management.

These various statutes simply remove what would otherwise be, under the duty of loyalty, an absolute prohibition against any such undertaking. ${ }^{155}$ It should not be assumed, however, that they relieve the trustee of normal duties to act fairly, in good faith, and within normal rules concerning reasonable overall compensation..$^{156}$ Also, the trustee must act in a manner consistent with general fiduciary principles of loyalty and impartiality, as well as having a duty to exercise investment authority in a manner that fully complies with the duty of prudence. ${ }^{157}$

154. Some readers will recall Professor Randall Roth's fascinating discussion at ACTEC's 1999 annual meeting in Maui of the "lead trustee" problem in the current Bishop Estate controversy in Hawaii.

155. See UN1F. TRusT CodE $\S 802$ (f) cmt. (Discussion Draft Feb. 9, 1999). On the duty of loyalty generally, see Restatement (SeCOND) of Trusts $\$ 170$ (1959); 2A Austin Wakeman ScotT \& William Franklin Fratcher, The LaW of Trusts $\$ \$ 170-170.24$ (4th ed. 1987).

156. See SR 99-7 (Fed. Res. Bd. 1999); Office of the Comptroller of the Currency, Interpretive Letter No. 704, Oct. 30, 1995; UNIF. Trust CodE $\$$ 802(f) cmt. (Discussion Draft Feb. 9, 1999); ThirdParty and Proprietary Funds-Fed Issues [2-30-99] Fiduciary Guidance, Trust Reg. News, Apr. 1999, at 1.

157. See investment discussion in infra Part VIII.A. 


\section{F. The Duty of Impartiality, Including "Productivity" and Principal-Income Accounting}

Trust law has long recognized the trustee's duty of impartiality, with an associated or "companion" duty to make the trust estate reasonably "productive" for the benefit of income beneficiaries-that is, productive of trust accounting income. These duties obligate the trustee to balance the competing objectives and concerns associated with the diverse beneficial interests in typical private trusts. Counterparts of these issues arise in charitable trusts, in which productivity is a concern whenever (as in typical institutional endowments) "income" is to be expended, or in any event whenever the interests of the "present" need to be balanced against the interests of the "future." The Uniform Management of Institutional Funds Act (UMIFA) attempts, reasonably successfully, to address concerns of this general type, mainly (for present purposes) with respect to investment and distributions.

The most important trend in these matters is a growing professional understanding, or at least awareness, of the subtle issues inherent in the duty of impartiality and in the duty with respect to productivity. Unfortunately, over the years, the true nature and implications of the duty of impartiality have been little explained, and vaguely defined at best, in the cases and literature. This is true even of the Internal Revenue Service's hazy insistence upon a normal state law degree of "productivity" in trusts with straight income interests that are intended to qualify for such privileges as the marital deduction and the gift tax annual exclusion. ${ }^{158}$ Analogous concerns about the ability to fairly value income interests led to the introduction of understandably arbitrary rules in the 1969 changes in the requirements for obtainmg charitable deductions for split-interest trusts and, more recently, for analogous transfer tax valuation problems in Internal Revenue Code chapter 14.

The prudent investor rule ${ }^{159}$ of Trusts Third includes a comprehensive but flexible duty of impartiality. It seeks to clarify and in some respects to broaden the contents of the duty, or at least to create sensitivity to the breadth of its potential application. ${ }^{160}$ The prudent investor volume's discussion of impartiality also identifies trust situations in which the "productivity" feature of this duty has little or no relevance. (Essentially, this is the case with respect to wholly discretionary trusts, annuity or unitrust arrangements, and-to a lesser degree-trusts with flexible powers to invade principal.) In addition, the commentary makes clear that a trustee's

158. See, e.g., I.R.C. $\$ \S 2056,2503$ (I998).

159. See infra Part VIII.A.

160. I have tried to spell this out in my article, Trust Investment Law in the Third Restatement, 27 Real Prop. Prob. \& Tr. J. 407, 441-45 (1992), as well as in Trusts Third: Prudent Investor, supra note 148, $\S 181,183,227 \mathrm{cmts}$. c \& i, 232. See also id. $\$ \S 239-240$. 
productivity concerns relate to the trust portfolio as a whole, rather than to each individual investment. ${ }^{161}$

\section{What Is "Impartiality"?}

The Trusts Third prudent investor rule also attempts to make clear that impartiality does not require an equal balancing of diverse interests, which may involve not only the obvious competing interests of income and remainder beneficiaries, but also the conflicting needs and objectives of multiple income beneficiaries or of multiple remainder beneficiaries. ${ }^{162}$ What this duty does call for is a balancing of interests in a manner consistent with the terms and purposes of the trust, including any ascertainable or inferred preferences of the settlor for some beneficiaries over others, such as the priority frequently intended for a surviving spouse over descendants or other holders of future interests. Essentially, the duty of impartiality forbids the trustee, "substantively," from injecting its own favoritism into the making of discretionary distributions or investment decisions, and, "procedurally," from consulting with or providing information to the life beneficiary to the exclusion of persons interested in the remainder. Thus, the concerns and wishes, and the personal, financial and tax circumstances, of the various beneficiaries are all to be taken into account in a manner consistent with the terms and objectives of the particular trust.

Finally, Trusts Third makes clear that a trustee must take account of the risks that inflation may pose to purchasing power and real values, again in a manner and to an extent consistent with the nature and objectives of the particular trust. This, however, does not mean that a trustee is liable for failing to achieve a particular goal when the trustee has acted with prudence. ${ }^{163}$

\section{Trust Design and Accounting}

The emphasis in the prudent investor rule of Trusts Third and of the Uniform Prudent Investor Act on strategies and objectives that are consistent with the purposes of each individual trust, and on portfolio theory and the benefits of investing for total return (essentially, income yield plus increase in corpus value), has stimulated the interest of trust practitioners in achieving an understanding of finance, or at least of basic financial theory. Grants from The American College of Trust and Estate Counsel Foundation have resulted in a valuable, concise text written for a lawyer audience and already in its second edition. ${ }^{164}$ Particularly useful for the

161. See Trusts ThIRD: PrUdent Investor, supra note $148, \$ 227 \mathrm{cmt}$. i.

162. See id. $\$ 227 \mathrm{cmt}$ i, 232.

163. See id.; see also id. $\$ 227 \mathrm{cmts.} c$, c.

164. See Jonathan R. Macey, An Introduction to Modern Financial Theory (2d ed. 1998); see also Burton G. Malkiel, An Update on Modern Financial Theory, 24 ACTEC NoTEs 127 (1998) (the ACTEC 1998 Joseph Trachtman Lecture). 
foreseeable future will be the recent professional writings and legislative proposals reflecting the importance of, and techniques for avoiding, conflicts between productivity requirements and optimal total-return investment objectives: (1) through revision of statutes governing principal and income accounting to include some form of special adjustment power to be used when proper and beneficial investment programs lead to inordinately low "income" yields; ${ }^{165}$ and (2) through creative trust design, often emphasizing unitrust life interests. ${ }^{166}$

\section{G. Trustees' Duties with Respect to Accounting and Disclosure}

A trustee's duty to provide information to beneficiaries on a reasonable basis has long been recognized as fundamental to the trust relationship. ${ }^{167}$ Nevertheless, practice, experience, and litigation in this country clearly demonstrate that there is considerable reluctance, and at least a fair amount of uncertainty, among fiduciaries concerning the applicability and performance of this general duty.

Although some duty to account is fundamental to the fiduciary relationship, this has not and should not be taken to mean that the terms of a trust cannot narrow, lower, raise, or otherwise alter the duty to render accountings, particularly routine or formal accountings. On the other hand, modern emphasis on the accepted principle that trusts are to be for the benefit of the beneficiaries has led in recent years to increased emphasis and clarification of the rights of beneficiaries to obtain information and copies of trust provisions, ${ }^{168}$ except to the extent the trust is subject to revocation by a legally competent settlor. ${ }^{169}$ Some recent legislation has been so

165. See the recently revised UNIFORM Principal \& INCOME ACT \& 104 (1997). The adjustment power stimulated legislative and law reform commission interest in developing other alternatives for adjustment, and even consideration of a default rule that would attribute a unitrust construction to a grant of a right to "income"-the likely outcome of current deliberations in New York.

166. Opening pieces in the growing dialogue on this subject were Robert B. Wolf, Defeating the Duty to Disappoint Equally-The Total Return Trust, 23 ACTEC NoTES 46 (1997); and William L. Hoisington, Modern Trust Design: New Paradigms for the 21st Century, 31 U. Miam1 HeckerLing InST. ON Est. PLAN. III 600-6I0 (1997). Then came Joel C. Dobris, Why Trustee Investors Often Prefer Dividends to Capital Gain and Debt Investments to Equity-A Daunting Principal and Income Problem, 32 Real Prop. Prob. \& Tr. J. 255 (1997); Jerold I. Horn, Prudent Investor Rule, Modern Portfolio Theory, and Private Trusts: Drafting and Administration Including the "Give-Me-Five" Unitrust, 33 Real Prop. Prob. \& TR. J. 1 (I998); and Robert B. Wolf, Total Return Trusts-Can Your Clients Afford Anything Less?, 33 Real Prop. Prob. \& Tr. J. 13I (1998). The latest, somewhat contrarian but valuable entry into this dialogue is James P. Garland, The Problens With Unitrusts, $1 \mathrm{~J}$. of Private Portfolio Mgmt. no. 4 (1999). On charitable trusts, see Stanley N. Lebergott, Nonprofits Should Rethink Investment Strategies, available in PUBLic AfFAlRs RePORT (Univ. of Calif., Sept. 1996).

167. See, e.g., GEorge T. Bogert, TRusts $\$ \S 140-142$ (6th ed. 1987) (hornbook); see also Shields v. Shields, 448 S.E.2d 436, 439 n.2 (Ga. I994) (surviving spouse life tenant required to account for "quasi-trusteeship" despite will provision purporting to excuse accountability).

168. See UNIF. TRust CodE $\$ 813$ (Discussion Draft Feb. 9, 1999).

169. See, e.g., id. \$ 8I3(e). 
forceful in recognizing and perhaps expanding the rights of beneficiaries that protests have been heard from some members of the Bar, ${ }^{170}$ particularly those whose practice includes representation of trustees but also some concerned about the wishes of client-settlors. Nevertheless, the trend of legislation and judicial decisions likely will continue to favor increased openness and disclosure in most situations involving irrevocable trusts. Illustrative is Trusts Third section 50 ("Enforcement and Construction of Discretionary Interests"), comment $b$, which states that discretionary beneficiaries are entitled "not only to accounting information but also to relevant information concerning the bases upon which the trustee's discretionary judgments have been or will be made." ${ }^{171}$

\section{Trusts Containing Powers of Appointment}

It is well recognized that principles of accountability and disclosure do not apply to actions of the donees (holders) of powers of appointment, the exercise of which may be arbitrary and need not be justified or explained as long as the scope of the power is not exceeded. ${ }^{172}$ It is not so clear, however, to whom the trustee's duties run when a trust contains powers of appointment; but it would seem clear enough that potential takers in default of appointinent (although probably not other objects-that is, permissible appointees - of an unexercised power) are "beneficiaries" of the trust and as such are entitled to notices and information, and that the donee of a power should also be so viewed. ${ }^{173}$

\section{Informal Accounting}

A popular, related development is the adoption or recommendation of statutes to authorize and facilitate informal accountings, and to authorize and simplify certain other actions out of court. Some recent legislative efforts of this type raise significant due process issues or are inconsistent with fundamental tenets of trust law, but sound models for legislation have been formulated in the last several years. (These models also offer guidance for parties wishing to proceed without specific statutory blessing.) Interested readers should examine recently modified Uniform Probate Code section $1-403^{174}$ and particularly the expanded version being proposed in Uniform Trust Code article 3. ${ }^{175}$

170. This has been true with respect to CAL. Prob. CoDE $\$ \S 16061,16061.5,16061.7$ (West 1998).

171. TRUSTs THIRD, supra note $2, \S 50 \mathrm{cmt}$. b.

172. See, e.g., id. $\S 50 \mathrm{cmt}$. a, although, as there noted, it is not always easy to draw a line between fiduciary and nonfiduciary powers.

173. See UNIF. TRUST CODE $§ 102$ (1) (Discussion Draft Feb. 9, 1999) (defining "beneficiary"); see also TRUSTs THIRD, supra note $2, \S 48 \mathrm{cmt}$. a.

174. 8 U.L.A. 69 (1998).

175. See UNIF. TRUST CoDE $\S \S 301-308$ (Discussion Draft Feb. 9, 1999). 


\section{H. Trust "Protectors"}

An important recent development in trust and estate planning practice, especially in connection with offshore trusts, has been the use of trust "protectors." The protector may be one of several trustees or a beneficiary, but often is neither, and may be granted extensive authority or just a narrowly defined power to change trustees or the situs of administration. Some protectors with broader authority are granted powers to clarify or modify trust terms for purposes such as: qualifying for or accomplishing some specific tax or nontax objective(s); improving administration or otherwise promoting the settlor's general purposes or the beneficiaries' best interests; or adding or eliminating beneficiaries or rearranging their rights.

The diverse types of protectors and the sheer variety of their uses and powers create serious difficulties in attempting to generalize about the nature of the protector's role and obligations. Under what circumstances and to what extent is a trust protector a fiduciary? Might some powers of some protectors be more like powers of appointment, perhaps even exercisable for the protector's personal or family benefit, with little accountability to others? There are also serious, relatively undeveloped choice of law and even jurisdictional issues to be explored, often in relatively novel circumstances. ${ }^{176}$ Unfortunately, trust law in this country shows virtually no appellate experience with or other legal development of the protector concept.

The present void in American trust doctrine aggravates the difficulty of interpretation and the issues of fiduciary responsibility that are an inevitable result of the novelty and diversity of trust protector provisionsnot to mention the risk of unanticipated, adverse tax consequences. All of this uncertainty leaves an immense challenge for estate planners in this country, who may find it helpful to look to England or elsewhere for legal developments or professional guidance in these aspects of trust design and drafting.

One might reasonably speculate that in the United States, absent some clear indication (possibly even circumstantial) of a settlor's contrary intent, the powers granted to a protector will be deemed to be held in a fiduciary capacity, even if not strictly that of trustee. (One might compare more traditional powers granted to others to direct trustees, considered in the 1999 draft of Uniform Trust Code section 808.) ${ }^{177}$ Such a fiduciary role might nevertheless provide considerable breadth of freedom to act in the

176. A somewhat related problem arose in a recent case, District of Columbia v. Chase Manhattan Bank, 689 A.2d 539 (D.C. Cir. 1997), which held that continuing contact between a Washington, D.C. domiciliary's testamentary trust and D.C. courts sufficed to satisfy the due process requirement of a significant link between the District and the trust to allow it to be treated by D.C. as a resident for income tax purposes.

177. See UnIF. Trust CODE $\$ 808$ (Discussion Draft Feb. 9, 1999). 
collective best interest of the beneficiaries, in good faith, with a general duty of impartiality, and in a manner consistent with the settlor's purposes in creating the trust and the office of trust protector. One might further speculate that, presumptively at least, it would be appropriate to treat a trust protector who has broad, "sole and uncontrolled," and "binding" discretion essentially as the common law of trusts and statutory trust law would treat a trustee holding a similarly "absolute" discretion. ${ }^{178}$

\section{Liability of Trustees}

One sigmificant trend in this area is the increasing recognition that, in the absence of a breach of trust, a trustee's liability to third parties (for contracts, torts, etc.) in the course of trust admimistration ordinarily is not personal hability, but liability in the trustee's fiduciary or "representative" capacity. ${ }^{179}$ Some other trends, concerning a trustee's liability to the trust or its beneficiaries, involve matters of fiduciary duty and standards and are discussed above in this Part VI or below in Part VII.

Important questions often arise regarding the measure of a trustee's liability when a breach of trust occurs. There is a widespread misunderstanding that the traditional so-called "no-netting rule," generally prohibiting the offsetting of gains against losses from breaches of trust, is an obstacle to a trustee's reliance on modern portfolio theory in trust investment. Trusts Third seeks to dispel this notion but also revisits this general subject to provide some fine-tuming for the antinetting principle, especially with respect to the distinction between singular and separate breaches. ${ }^{180}$ More important is a change of direction in Trusts Third calling for a trustee's liability for improper investment conduct to be based on a totalreturn, positive or negative, measure of damages. ${ }^{181}$ This approach would generally allow surcharge recoveries to reflect gains and losses in value that reasonably could have been expected from an appropriate investment program, rejecting the counterproductive and unnecessary traditional

178. See supra Part VI.B. See also Restatement (SECOND) of Trusts $\$ 187 \& \mathrm{cmts} . \mathrm{j}, \mathrm{k}$ (1959), TRUSTs THIRD, supranote $2, \S 50 \mathrm{cmt}$. c \& reporter's notes (collecting and discussing authorities), and UNIF. TRust CODE $\$ \$ 801,814$ (Discussion Draft Feb. 9, 1999), all of which essentially agree that even a trustee with such extended discretion as a settlor may properly confer has the duty to act in good faith and in a manner consistent with the terms and purposes of the discretionary power. See generally Antony Duckworth, Protectors-Fish or Fowl? (Part II), 5 J. OF lNT'L TR. \& CoRP. PLAN. 18, 18-19 (1996) (under the heading "Administrative Powers-Purpose Restrictions"); Donovan W.M. Waters, The Protector: New Wine in Old Bottles?, in TREnds in Contemporary TRust Law 63 (A.J. Oakley ed. 1996). Note, however, the comment to UNIFORM TRUST CODE $\$ 814$ (Discussion Draft Feb. 9, 1999), above, reminding that the section applies only to powers held in a fiduciary capacity.

179. See supra Part II.B.

180. See Trusts Third: Prudent lnvestor, supra note 148, $\S 213$ (containing partial, preliminary modification of $\S 213$ of the prior Restatement).

181. See id. $\$ \S 205,208-211$ (providing partial, preliminary modification of $\$ \$ 205,208-211$ of the prior Restatement). 
notion that such liability is, with narrow exceptions, too speculative. ${ }^{182}$ The new rule should ensure that trustees who have ignored important aspects of their fiduciary responsibilities through inadequate investment strategies will not be insulated from liability merely because their investment programs have escaped loss of dollar value during periods of significantly rising markets.

VIII

Investment AND Management of Trust Property

\section{A. Trust Investment Law}

Probably the most significant and pervasive influence on fiduciary standards in this country in the last decade has been, and into the future probably will be, the new "Prudent Investor Rule." The rule originated in a special, initial volume of the Trusts Third project, approved by the American Law Institute in $1990 .{ }^{183}$ The rule was soon codified in several states and then set out in a Uniform Act. The Uniform Prudent Investor Act was promulgated in 1994 by the National Conference of Commissioners on Uniform State Laws and is thereby recommended by NCCUSL for codification in all states. The modernized rule has already been enacted or otherwise recognized as law in at least three-quarters of the American jurisdictions.

In earlier periods of the twentieth century, the so-called "prudent man rule" gradually became the dominant rule of trust investment law in the various states, generally displacing less flexible approaches, such as "legal lists" of permissible investments. The classic prudent man dictum, subsequently quoted or paraphrased in other cases and treatises, appeared in Harvard College v. Amory ${ }^{184}$ more than a century and a half ago. More recently (some three decades ago), with slight paraphrasing of that dictum, Restatement (Second) of Trusts section 227 instructed trustees "to make such investments and only such investments as a prudent man would make of his own property having in view the preservation of the estate and the amount and regularity of the income to be derived." 185 This and earlier statements of general principles of care, skill, and caution (collectively,

182. Why and how this modernized approach would be used is explained, and relevant experience and authorities are cited, in id. $\S 211$ reporter's notes. See also Edward C. Halbach, Jr., Trust Investment Law in the Third Restatement, 27 Real Prop. Proв. \& TR. J. 407, 458-62 (1992). This approach was recently adopted, correctly in a potentially difficult situation, in Estate of Wilde, 708 A.2d 273 (Me. 1998). See also Noggle v. Bank of America, 70 Cal. App. 4th 853 (Ct. App. 1999).

183. See Trusts ThiRd: PRUdEnT Investor, supra note 148 . The main provisions of the rule are still, temporarily, presented as $\$ \S 227-229$. The contents of this volume, however, with accompanying modifications of other sections of the prior Restatement, will eventually be incorporated into the comprehensive Trusts Third treatise as the project continues, and will be renumbered and relocated in the appropriate volume.

184. 26 Mass. (9 Pick.) 446 (1830).

185. RESTATEMENT (SECOND) OF TRUSTS § 227 (1959). 
"prudence") were developed, applied and elaborated in case law. Generalizations were articulated and efforts were made to provide guidance to trustees, with the result that over time the prudent man rule lost much of its generality and adaptability as applied in most states (an unfortunate development that generally has been avoided in Massachusetts, the rule's birthplace).

America's leading trust law scholar, the late Professor Austin Scott, acknowledged that "what was decided in one case as a question of fact tend[ed] to be treated as a precedent establishing a rule of law"186 although his own work contributed significantly to this unfortunate tendency. ${ }^{187}$ Thus, the tendency was "to lay down definite subsidiary rules on what is and what is not a prudent investment" and to treat a case disapproving a particular investment by a trustee "as a precedent holding that no investment of that type is proper." ${ }^{1188}$ As a result, general standards often became crystallized into doctrine prescribing, with varying degrees of specificity and usually with some recognition of the benefits of diversification, the permissible types and characteristics of trust investments. These rules were generally based on some perceived but undefined degree of risk that exceeded the limits of "caution." With investments so classified and judged in isolation, and with broad categories of assets or courses of action branded as "speculative," trustees in surcharge actions had found it difficult, if allowable at all, to show that a particular investment or strategy falling outside the approved categories was prudent in a particular case.

Knowledge, experience and practices in the modern investment world demonstrate that many prohibitions under the traditional prudent man rule were unwarranted and likely to be counterproductive, inhibiting the exercise of sound judgment by skilled fiduciaries and creating risks of unjustified liability for all trustees. Well documented and generally compelling bodies of theoretical and empirical research (including scholarship recognized by a Nobel Prize in economics), as well as considerable professional hiterature, support these criticisms of the traditional prudent man rule. ${ }^{189}$

The prudent investor rule of Trusts Third section 227 states the "General Standard of Prudent Investment" as follows:

The trustee is under a duty to the beneficiaries to invest and manage the funds of the trust as a prudent investor would, im light

186. 3 Austin Wakeman SCOTT, THE LaW OF TRUSTS $\$ 227$ ( $2 \mathrm{~d}$ ed. 1956).

187. See id.; see also section 227 of the first and second Restatements of Trusts, for which Scott was the reporter.

188. 3 Austin Wakeman Scott \& William Franklin Fratcher, The Law of Trusts 434-35 (4th ed. 1988).

189. See, e.g., Bevis Longstreth, Modern Investment Management and the Prudent MAN Rule (1986); Harvey E. Bines, Modern Portfolio Theory and Investment Management Law: Refinement of Legal Doctrine, 76 Colum. L. REv. 721 (1976); see also TRUsTs THIRD: PRUDENT INVESTOR, supra note $148, \S 227$ reporter's notes (providing a comprehensive list of references). 
of the purposes, terms, distribution requirements and other circumstances of the trust.

(a) This standard requires the exercise of reasonable care, skill and caution, and is to be applied to investments not in isolation but in the context of the trust portfolio and as a part of an overall investment strategy, which should incorporate risk and return objectives reasonably suitable to the trust. ${ }^{190}$

Clause (b) of this standard imposes a forceful but nevertheless flexible duty to diversify trust investments, while Clause (c) requires compliance with the "fundamental fiduciary duties of loyalty and impartiality"191 and of prudence in delegation, ${ }^{192}$ and also emphasizes the increasingly important duty of the trustee to be cost conscious in the discharge of trust investment responsibilities. ${ }^{193}$ These various principles are explained and illustrated through almost 100 pages of official commentary and reporter's notes, ${ }^{194}$ and they are carefully stated again in the Uniform Prudent Investor Act. Also, Part VII.F discusses the trust law's traditional requirement of income "productivity" in investment as an aspect of the broader duty of impartiality (including a general duty to take account of the effect inflation may have on purchasing power), along with the effects of and legal and planning responses to the productivity requirement.

\section{B. Trust Management Generally}

A fundamental premise of the prudent investor rule is that no investment or course of action is per se impermissible. ${ }^{195}$ Counterparts of this principle can be expected to apply pervasively to matters of trust administration, and to appear throughout the administration chapters of Trusts Third. ${ }^{196}$ Traditional questions about whether a trustee possesses particular powers will be replaced by recognition that, absent contrary trust provision or statute, a trustee has all the powers of other property owners, but with a duty of prudent exercise and compliance with other fiduciary standards.

Accordingly, the trust law of the future will not ask whether or for what purposes a particular power exists but will focus simply on the circumstances and manner of its exercise-as illustrated by the substantial reversal in the last decade of the law's negative attitude toward delegation

190. Trusts ThiRd: Prudent INvestor, supra note $148, \S 227$ (a).

191. See supra Parts VII.E and VII.F.

192. See supra Part VII.D.

193. TRUSTS ThIRD: PRUdENT INVESTOR, supra note 148, § 227(b)-(c).

194. See id. \$ $227 \mathrm{cmts.} \mathrm{\&} \mathrm{reporter's} \mathrm{notes.}$

195. See Uniform Prudent Investor Act § 2(e) \& cmts. (1999) (especially "Abrogating categoric restrictions"); Trusts ThIRD: PRUdent INvestor, supra note 148, at 5 (Introduction, "Principles of Prudenee").

196. On the extension of such a principle to administrative powers generally in England (as should be expected in the United States as well), see Trusts of Land and Appointment of Trustees Act $1996 \S$ $6(1)$. 
by trustees. ${ }^{197}$ The prudence of a trustee's conduct in a particular case will then be judged in its full context-without arbitrary or categorical prohibitions-in light of the terms, purposes and other circumstances of the particular trust, as well as the trustee's general duty to act with prudence and to comply with the fundamental fiduciary duties of loyalty and impartiality.

\section{IX \\ Concluding OBSERvations}

The thirty years since the promulgation of the original Uniform Probate Code, and especially the last decade, have involved a dramatic awakeming in the traditionally stable fields of probate and trust law. The foregoing review does not encompass all developments in this period, or even all ongoing trends, affecting the American law of trusts. It sets forth this writer's recollection and perception of the more significant of those current and continuing trends that are likely to affect trust practice and estate planming well into the foreseeable future-or, as it seems we are now expected to say, into the next millennium.

Some of the trends noted here either liberalize or tighten mandatory rules that direct how trusts are to be created or that limit trust purposes and the effects trust provisions may have. Most of the trends, however, involve-as does most of the trust law-default rules. These rules yield to intentions adequately manifested by settlors, but they supply or construe distributive and administrative terms of trusts, and prescribe duties of trustees, to the extent settlors have failed to do so or have been unclear. With a couple of exceptions that no doubt are evident to the reader, the above-described developments and trends seem to this writer (not surprisingly) to represent progress in both mandatory and default features of the law of trusts. That is, the current directions of change are designed to reflect sound social policy and to enhance the utility of the trust device to property owners and their intended beneficiaries, including by increased admimstrative efficiency and reduced planning complexity and risk. As observed in the Introduction, a pervasive theme of recent and continumg trends is to uphold intended trusts, despite techmical defects when it is safe to do so, and to give effect to the ascertainable or probable, and legally permissible, intentions of settlors.

197. See supra Part VII.D. 
